Karakuş, N., Esendemir, N., Ucuzsatar, N. ve Karacaoğlu, M. Ö. (2021). Türkçe dersleri özelinde uzaktan eğitim hakkında veli görüşleri. Ana Dili Eğitimi Dergisi, 9(3), 993-1011.

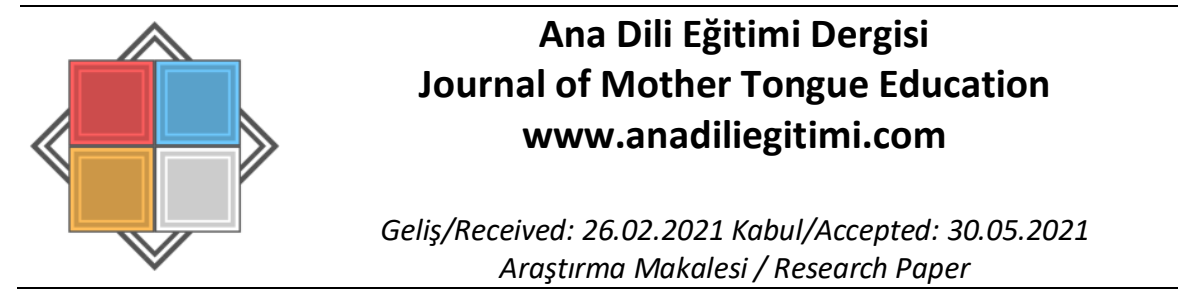

\title{
Türkçe Dersleri Özelinde Uzaktan Eğitim Hakkında Veli Görüşleri
}

\author{
Neslihan KARAKUŞ* \\ Nurullah ESENDEMIR* \\ Nil UCUZSATAR ${ }^{* * *}$ \\ Mehmet Önder KARACAOĞLU $U^{* * *}$
}

\begin{abstract}
Öz
Koronavirus (Covid-19) salgını, içinde eğitimin de olduğu birçok alanda büyük çaplı değişimlere yol açmış; eğitimin tüm kademelerinde dersler, uzaktan eğitimle işlenmeye başlanmıştır. Uzaktan eğitim gittikçe daha fazla tercih edilen bir seçenek olsa da salgın sürecinde alınan tedbirler kapsamında ilk kez büyük çapta uygulanmış ve yüz yüze eğitime bir alternatif olarak değerlendirilmiştir. Öğretmen ve öğrenciyle birlikte eğitimin en önemli paydaşı olan velilerin uzaktan eğitime yönelik görüşlerinin araştırılması sürecin verimliliğin değerlendirilebilmesi açısından önemlidir. Bu bağlamda bu çalışmanın amacı, ortaokul öğrenci velilerinin Türkçe derslerinin uzaktan eğitimle işlenmesine dair görüşlerini belirlemektir. Nitel araştırma desenlerinden durum çalışması ile yapılandırılan araştırmanın çalışma grubunu, Manisa'nın Salihli ilçesinde ikamet etmekte olan 102 veli oluşturmaktadır. Araştırmanın verileri, 21 maddelik bir anket aracılığıyla Google Forms üzerinden çevrimiçi ortamda toplanmış, içerik analiziyle çözümlenmiş; velilerin Türkçe derslerinin uzaktan eğitimle işlenişine yönelik görüşlerinin genel itibariyle olumsuz olduğu belirlenmiştir. Velilerin görüşleri doğrultusunda uzaktan eğitim sürecinde Türkçe derslerinin verimliliğinin artırılması adına çözüm önerileri geliştirilmiştir.
\end{abstract}

Anahtar Kelimeler: Uzaktan eğitim, Türkçe dersleri, veli görüşleri, Covid-19.

\section{Distance Education from Parents' Perspectives : A Study on Turkish Lessons}

\section{Abstract}

Coronavirus (Covid-19) epidemic, has led to major changes in many areas including education. Lessons at all levels of education began to be taught with distance education. Although distance education is an increasingly preferred option, it has been applied on such a large scale for the first time within the scope of the measures taken during the Covid-19 and has been considered as an alternative to face-to-face training. Researching the opinions of parents, who are one of the most important stakeholders of education, on distance education is significant in terms of evaluating the efficiency of the process. In this context, the study aims to reveal the opinions of middle school students' parents about teaching Turkish lessons with distance education. The study group of the research, which is structured with a case study, one of the qualitative research designs, consists of 102 parents residing in Salihli district of Manisa, Turkey. The data of the research were collected online on Google Forms via a 21-item questionnaire and analyzed using content analysis; it was

\footnotetext{
${ }^{*}$ Doç. Dr., Yıldız Teknik Üniversitesi, Eğitim Fakültesi, Türkçe ve Sosyal Bilimler Eğitimi Bölümü, Türkçe Eğitimi ABD, İstanbul, neslihankarakush@gmail.com, ORCID: orcid.org/0000-0001-7808-1099.

** Arş. Gör., Yıldız Teknik Üniversitesi, Sosyal Bilimler Enstitüsü, İstanbul, esendemirnurullah@gmail.com, ORCID: orcid.org/0000-0001-6841-2552.

*** Arş. Gör., Yıldız Teknik Üniversitesi, Eğitim Fakültesi, Türkçe ve Sosyal Bilimler Eğitimi Bölümü, Türkçe Eğitimi ABD, İstanbul, nilucz9063@gmail.com, ORCID: orcid.org/0000-0001-6019-5880.

${ }^{* * * *}$ Dr. Öğrencisi, Yıldız Teknik Üniversitesi, Sosyal Bilimler Enstitüsü, Türkçe Eğitimi Doktora Programı, İstanbul, mehmetonder25@gmail.com, ORCID ID: 0000-0002-4461-6021.
} 
determined that the opinions of the parents of the students about the teaching of Turkish lessons with distance education were generally negative. In line with the opinions of the parents of the students, solutions were developed in order to increase the efficiency of Turkish lessons in the distance education process.

Keywords: Distance education, Turkish lessons, parents' opinion, Covid-19.

\section{Giriş}

Çin Halk Cumhuriyeti'nin Wuhan şehrinde 2019 yılının son aylarında ortaya çıkan ve çok kısa bir süre içerisinde hızla bütün dünyaya yayılan Koronavirüsü, birçok alanda çok derin tesirler meydana getirmiştir. İnsan sağlığını tehdit eden virüs, tüm dünyada çok sayıda kişinin ölümüne sebebiyet vermiştir. Bu yüzden 11 Mart 2020 tarihinde Dünya Sağlık Örgütü (DSÖ), virüsü "pandemi” olarak ilan etmiştir (WHO, 2020). Covid-19 olarak da anılan ve DSÖ tarafından salgın olarak nitelenen hastalık; sosyal, ekonomik, kültürel ve politik zeminlerde dünyayı ciddi bir değişime zorlamıştır. Salgın sebebiyle spor müsabakaları ertelenmiş, camiler kapatılmış, sanatsal ve kültürel faaliyetler iptal edilmiştir (Gümüşgül ve Aydoğan, 2020). Insanların toplu gerçekleştirdikleri etkinlikler durdurulmak suretiyle salgının yayılmasının önüne geçilmek istenmiştir.

Virüsün bütün dünyayı etkisi altında alması; sağlık, kültür ve ulaşım başta olmak üzere birçok alanda düzenleme yapmayı zorunlu kılmıştır (Eren, 2020). Birçok saha ve sektör, salgından ötürü geçici bir süreyle de olsa değişmek ve dönüşmek durumunda kalmıştır. Eğitim de Covid-19 nedeniyle büyük değişim ve dönüşüm geçiren kurumların arasında yer almaktadır (Kırık, 2016; Can, 2020; Telli Yamamoto ve Altun, 2020).

Eğitimin salgın süreci dolayısıyla yaşadığı değişimi daha rahat gözlemlemek için bu durumdan etkilenen öğrenci sayısına bakılabilir. UNESCO (2020), 17 Nisan 2020 tarihi itibariyle 191 farklı ülkede toplamda 1.724.657.870 öğrencinin Covid-19 salgını sürecinden etkilendiğine ilişkin istatistik yayınlamıştır. Eğitimi kesintiye uğrayan öğrenci oranının, toplam öğrenci sayısının \%90'ına tekabül ettiği belirtilmektedir (Eren, 2020). Dünya üzerindeki öğrencilerin büyük çoğunluğu salgından ciddi bir biçimde etkilenmiştir. Bu etkiler, öğrenci sayısının da çok üzerinde olup eğitimin geneline dair görüşleri değiştirecek düzeye ulaşmıştır. Bozkurt ve Sharma (2020), Covid-19 salgınının yarattığı fırtınadan ciddi bir biçimde etkilendiğine dikkat çekerek yaşanan sürecin eğitime bakışı değiştirdiğini belirtmektedir. Koranavirüsün patlak vermesiyle eğitimin kabuk değiştirmeye başlama safhasının başladığı yönünde kanaatler bulunmaktadır (Yamamoto ve Altun, 2020).

11 Mart 2020 günü ülkemizde ilk Koronavirüs vakasının tespit edilmesinin ardından Millî Eğitim Bakanlığı (2020), derhal bir eylem planı hazırlığına girmiş ve kısa bir süre içinde eğitim kurumlarının yüz yüze eğitime kapandığını ilan etmiştir. Öğrenci, veli ve öğretmenlerin sağlıklarını koruma adına iki hafta süreyle ülke genelindeki tüm okullar tatil edilmiştir (MEB, 2020). Salgının ilerlemesini önlemek ve yavaşlatmak adına alınan tedbirler kapsamında okulların kapatılmasına ve eğitim sürecinin uzaktan eğitim yöntemiyle yürütülmesine karar verilmiştir. Türkiye Radyo ve Televizyon kanalları (TRT EBA TV) ve Eğitim Bilişim Ağı (EBA) üzerinden uzaktan eğitimin yürütüleceği duyurulmuştur. Bu bağlamda dersler, internet ve TV yayınları aracılığıyla işlenmeye başlanmıştır.

Kısa bir süre öncesine dek yüz yüze ve sınıf ortamında devam eden eğitim-öğretim sürecinin uzaktan eğitim platformlarına taşınması, başta öğretmen ve öğrenciler olmak üzere eğitimin tüm paydaşlarının bu yeni sürece intibakını gerekli kıımıştır. Zira uzaktan eğitim, yüz yüze eğitimden farklı bir yöntem olarak öne çıkmaktadır. Geleneksel eğitim, eğitim binası içerisinde ve sınıf ortamında öğretmen ve öğrencilerin fiziki olarak bir arada bulunduğu ve bir etkileşim içine girerek öğrenme sürecini şekillendirdiği bir yöntemdir. Öte yandan uzaktan eğitim, öğreten ve öğrenen öznelerin birbirinden uzakta bulunduğu bir eğitim düzeneğidir (Ağaoğlu, İmer ve Karabacak, 2002). Uzaktan eğitim; bilişim ve internet imkânlarından yararlanılarak eğitim ortamlarında değişim yaratma potansiyeli taşımaktadır (Ateş, 2010). Uşun (2006) için, bilgi kaynağının ve alıcıların birbirinden uzakta olduğu uzaktan eğitim uygulamaları, bireyselleştirilebilir ve esnetilebilir özellikler taşımaktadır.

Esasında uzaktan eğitim, günümüzde ortaya çıkan bir kavram değildir. Çağımızdan önceki dönemlerde de bu eğitim yönteminin farklı formatlarda da olsa kullanılageldiği söylenebilir. Uzaktan eğitimin tarihçesine bakıldığında bundan yüzyıllar evvel mektuplar aracılığıyla eğitim verildiği, gazete, 
radyo ve televizyon gibi teknik imkânlarla bu eğitimin devam ettirildiği, bilgisayar teknolojileriyle birlikte dünyanın her tarafında yaygın bir şekilde kullanılmaya başlandığı ve gün geçtikçe daha fazla insana hitap ettiği göze çarpmaktadır (Clark, 2020). Ülkemizde de başta Anadolu Üniversitesinin Açık ve Uzaktan Eğitim Fakültesi (AÖF) olmak üzere birçok kurum ve kuruluş bünyesinde uzaktan eğitim çalışmaları sürdürülmektedir (Yamamoto ve Can, 2013).

Esnek bir yapıya sahip olması (Uşun, 2006), zaman ve mekân sınırlarını kaldırması (Arat ve Bakan, 2014), eğitim maliyetlerini düşürüp erişilebilirliği artırması (Traxler, 2018), toplumsal cinsiyet eşitliğine katkı sunması (Ferdousi, 2010), kırılgan gruplar da dâhil olmak üzere toplumun bütün kesimlerine hitap edip ulaşabilmesi (Khan ve Williams, 2007; Odabaş, 2003) gibi özellikleri nedeniyle uzaktan eğitim, yüz yüze eğitime nazaran daha avantajlı olarak değerlendirilmektedir. Bütün bu avantajlarına karşın uzaktan eğitimin birtakım dezavantajları da bulunmaktadır. Bu dezavantajları; öğretmen ve öğrenci arasındaki etkileşimin sınırlı kalması (Duran, 2020), uzaktan eğitim kaynaklarına eşit erişimin olmayışından ötürü dijital uçurum tehlikesinin bulunması (Sezgin ve Fırat, 2020), dikkat dağınıklığına sebebiyet verdiği için ders verimini düşürmesi (Elcil ve Şahiner, 2014), teknik aksaklıkların yaşanması (Altıparmak, Kurt ve Kapıdere, 2011) şeklinde özetlemek mümkündür.

Yukarıdaki kıyaslamadan da anlaşılacağı üzere uzaktan eğitim, geleneksel eğitimden farklı bir şekilde gerçekleşen, kendine özgü fırsat ve riskleri bulunan bir eğitim türüdür (Demir, 2014). Geleneksel eğitimden farklı bir yapıya sahip olan uzaktan eğitim, alan yazında kendine has dinamikleriyle ele alınıp incelenmiştir. Özellikle de Covid-19 salgınının patlak vermesinden sonra başlayan süreçte uzaktan eğitime ilişkin çalışmalarda büyük bir artış yaşanmıştır (Can, 2020; Başaran ve diğ., 2020; Akyürek, 2020). Bu çalışmalardan bazıları üniversite öğrencileriyle (Duran, 2020; Karakuş vd., 2020; Elcil ve Şahiner, 2014; Keskin ve Kaya, 2020), bazıları üniversite mezunlarıyla (Kan Kılınç vd. 2020), bazıları lisansüstü öğrencileriyle (Ağaoğlu, İmer ve Karabacak, 2002), bazıları öğretmenlerle (Bakioğlu ve Çevik, 2020; Bayburtlu, 2020; Kantos, 2020), bazılarıysa öğrencilerle (Sinem ve Baş, 2020; Başaran vd., 2020) gerçekleştirilmiştir.

Uzaktan eğitime dair alanyazın incelendiğinde eğitimin hemen hemen tüm paydaşlarının üzerinde araştırma yapıldığı, öte yandan öğrencilerin anne babalarının daha az sayıda çalışmaya konu edildiği görülmektedir. Velilerle ilgili yapılan çalışmaların bazısında aynı anda öğretmen, öğrenci ve veli görüşleri alınmış (Başaran vd., 2020), kimi çalışmada ise (Yılmaz, Mutlu ve Doğanay, 2020) herhangi bir alt alan ayrımı gözetmeksizin uzaktan eğitime dair genel algılar belirlenmeye çalışılmıştır. Uzaktan eğitim sürecinde Türkçe eğitiminin yürütülmesine ilişkin veli görüşlerine müracaat edilen müstakil bir çalışmaya rastlanmamıştır. Yapılandırmacı yaklaşım bağlamında düşünüldüğünde velilere eğitim sürecinde yol gösterme, gözlemcilik yapma, sorun çözümüne yardımcı olma, teşvik etme, araştırmaya yöneltme gibi önemli görevler düşmektedir (Yaşar, 2010). Eğitimin önemli bir paydaşı olarak görülen velilerin, Covid-19 salgınıyla hız kazanan uzaktan eğitim sürecinde Türkçe eğitimine ilişkin görüşlerinin belirlenmesi önem arz etmektedir. Bu sebeple alanyazında görülen bu boşluğu doldurmaya matuf bu çalışmanın amacı, öğrenci velilerinin, Türkçe derslerinin uzaktan eğitimle işlenişine dair görüşlerini ortaya çıkarmaktır.

\section{Araştırmanın Modeli}

\section{Yöntem}

$\mathrm{Bu}$ araştırma, nitel araştırma yöntemlerinden biri olan durum çalışması deseni ile gerçekleştirilmiştir. Durum çalışmaları, sınırlı bir sistemin çoklu bilgi kaynakları kullanılarak detaylı toplanan bilgilerle (Creswell, 2016) derinlemesine betimlendiği ve incelendiği (Merriam, 2018) çalışmalardır. Araştırmada uzaktan eğitime yönelik veli görüşleri tek bir analiz birimi olarak ele alınmış ve araştırma "bir durumun tek parça olarak bütünsel bir biçimde incelendiği" (Saban ve Ersoy, 2017) bütüncül tek durum deseni ile yapılandırıımıştır.

\section{Araştırmanın Çalışma Grubu}

Nitel araştırmalar, nicel araştırmaların aksine derinlemesine bilgi edinilebilecek ve kendi bağlamını oluşturmuş olan küçük örneklem gruplarıyla gerçekleştirilir (Miles ve Huberman, 2016). Bu araştırmanın çalışma grubunun belirlenmesinde kolay ulaşılabilir örnekleme yöntemi kullanılmıştır. Bu 
yöntem, araştırmanın amaçlarına uygun olmak suretiyle araştırmacılara pratiklik, ekonomiklik ve hız kazandırmak adına yakın çevreden bireylerin seçimidir (Yıldııım ve Şimşek, 2016). Bu araştırmanın çalışma grubunu, Manisa iline bağlı Salihli ilçesinde ikamet etmekte olan 102 ortaokul öğrenci velisi oluşturmaktadır. Katılımcıların 69'u $(\% 67,6)$ kadın ve 33'ü $(\% 32,4)$ erkektir.

Katılımcıların yaş bilgileri Şekil 1.'de belirtilmiştir:

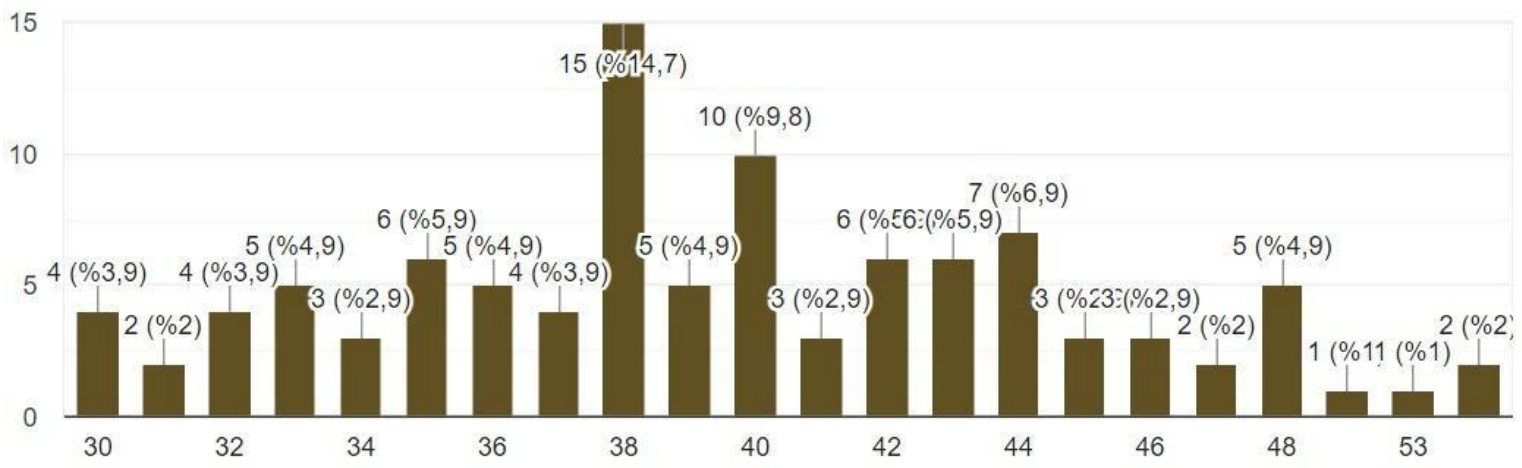

Şekil 1. Katılımcıların Yaş Bilgileri

Çalışma grubunun öğrenci velilerinden oluşmasından ötürü katılımcı yaş grubu çeşitlilik göstermektedir. Şekil 1.'den hareketle en fazla $(f=15, \% 14,7)$ tekrar eden değerin 38 olduğu görülür. Ardından $(f=10, \% 9,8) 40$ değeri gelmektedir. Öğrenci velilerinin yaşları, en az 30 , en fazla 55 olacak şekilde $30-55$ yaş aralığında dağılım göstermektedir.

Katılımcı grubun sosyo-ekonomik düzeyi hakkında bir fikir edinmek adına, veri toplama aracında kişisel bilgiler kısmında velilerin meslekleri sorulmuştur. Veli cevapları aşağıdaki şekilde gösterilmektedir:

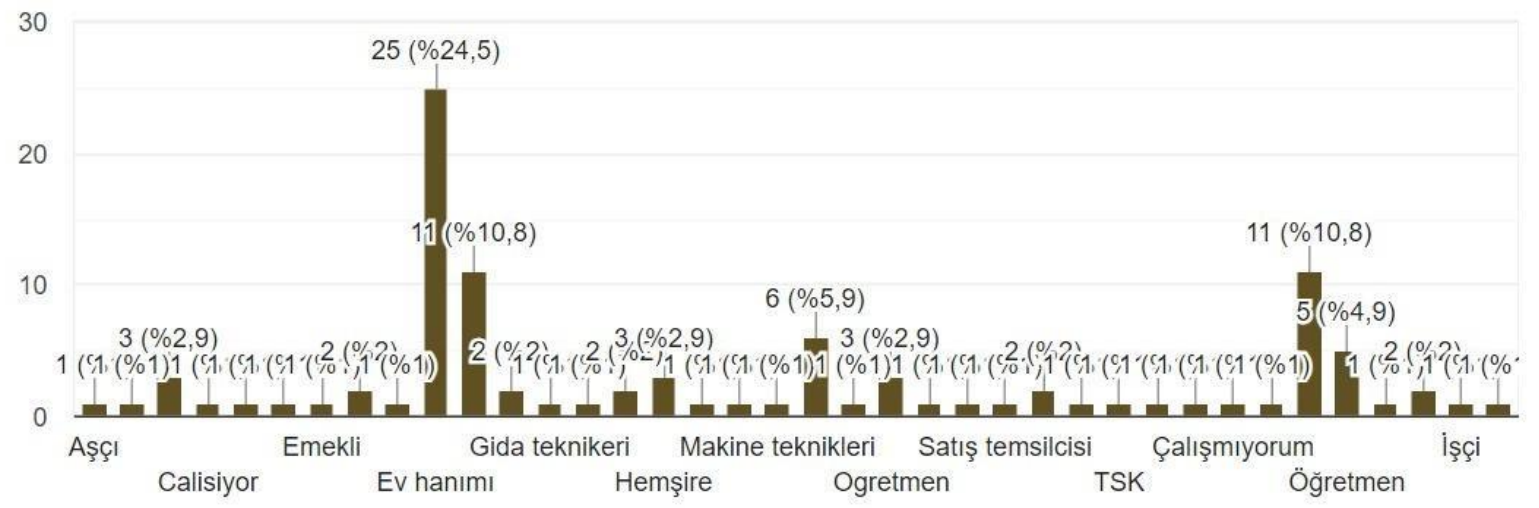

Şekil 2. Katılımcıların Meslek Bilgileri

Şekil 2.'ye göre araştırmaya katılan velilerin en fazla $(\% 24,5)$ ev hanımı grubundan olduğu görülür. Bu durum, katılımcıların \% 67,6'sının kadın olmasıyla ilişkili olabilir. Öğretmen ve gıda teknikeri grupları da \% 10,8 oranlarla en fazla verilen cevaplar arasındadır.

Araştırmaya katılan velilerin çocuklarının sınıf düzeylerine ilişkin bilgiler Şekil 3.'te belirtilmiştir: 


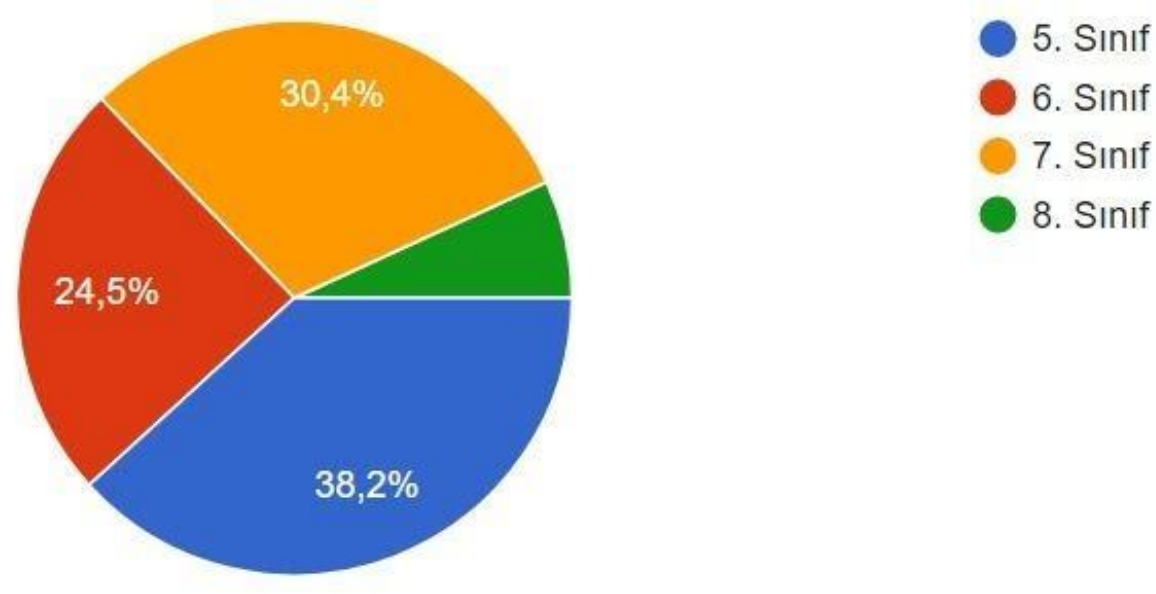

Şekil 3. Katılımcı Velilerin Çocuklarının Sınıf Düzeyleri

Çalışma grubunda yer alan velilerin çocuklarının 39'u $(\% 38,2) 5$. sınıfta, $25^{\prime} i(\% 24,5) 6$. sınıfta, 31 'i $(\% 30,4) 7$. sınıfta ve 7'si $(\% 6,9) 8$. sınıfta öğrenim görmektedir.

\section{Veri Toplama Araçları, Verilerin Toplanması ve Analizi}

Araştırmanın veri toplama aracı, alan uzmanlarının görüşleri doğrultusunda yapılandııılmış, çevrimiçi ortamda Google Forms üzerinde hazırlanan 21 maddelik bir anket formudur. Hazırlanan anketin ilk 7 maddesinde öğrenci velilerinin demografik bilgilerine ait sorular yer almaktadır. Bu kısımda yaş, meslek, cinsiyet, eğitim durumu, uzaktan eğitimde kullanılan araçlar, uzaktan eğitim kullanım geçmişi ve çocuklarının sınıf düzeyi bilgileri sorulmuştur. Geri kalan 14 maddede ise öğrenci velilerinin Türkçe eğitimi özelinde uzaktan eğitim sürecine ilişkin görüşlerini belirlemeye yönelik derecelendirme ölçekleri ve bunların nedenselliğine dair açık uçlu sorular yer almaktadır.

Illgili alan yazın taranarak hazırlanan anket taslağı; 3'ü Türkçe eğitimi, 2'si ölçme değerlendirme alanlarında olmak üzere 5 farklı alan uzmanının görüşleri doğrultusunda tekrar düzenlenmiş, dönütler ışığında düzeltilen forma son şekli 5 öğrenci velisiyle yapılan pilot uygulamanın ardından verilmiştir.

Öğrenci velilerinin uzaktan eğitimle Türkçe eğitimi verilmesi sürecine ilişkin görüşlerini tespit etmeye yönelik hazırlanan 21 maddelik anket Google Forms üzerinden elektronik ortamda öğrenci velileri ile paylaşılmıştır.

Verilerin analiz sürecinde hem içerik analizinden hem de betimsel analizden faydalanılmıştır. İçerik analizi; genel olarak "belirli temalara veya kategorilere göre nitel veya nicel verilerin sistematik kodlanması" şeklinde tanımlanabilir (Dinçer, 2018). İçerik analizi ile kategorilendirilen veriler, "verilerin daha önceden belirlenmiş temalara göre özetlenip yorumlandığı" betimsel analiz ile yorumlanmıştır (Özdemir, 2010).

\section{Araştırma ve Yayın Etiği}

Bu çalışmada "Yükseköğretim Kurumları Bilimsel Araştırma ve Yayın Etiği Yönergesi" kapsamında uyulması belirtilen tüm kurallara uyulmuştur. Yönergenin ikinci bölümü olan "Bilimsel Araştırma ve Yayın Etiğine Aykırı Eylemler" başlığı altında belirtilen eylemlerden hiçbiri gerçekleştirilmemiştir.

\section{Etik Kurul İzi}

Kurul adı $=$ Yıldız Teknik Üniversitesi

Karar tarihi $=25.09 .2020$

Belge sayı numarası $=2009250012$ 


\section{Uygulama Izni}

Kurul adı = Milli Eğitim Bakanlığı

Karar tarihi $=27.11 .2020$

Belge sayı numarası 17365429

\section{Bulgular}

Araştırma kapsamında elde edilen veriler, içerik analizi tekniğiyle çözümlenerek 6 farklı tema altında listelenmiş ve katılımcıların uzaktan eğitime ilişkin düşünceleri ortaya konulmuştur.

\section{Uzaktan Eğitim Kullanım Düzeylerine İlişkin Veli Görüşleri}

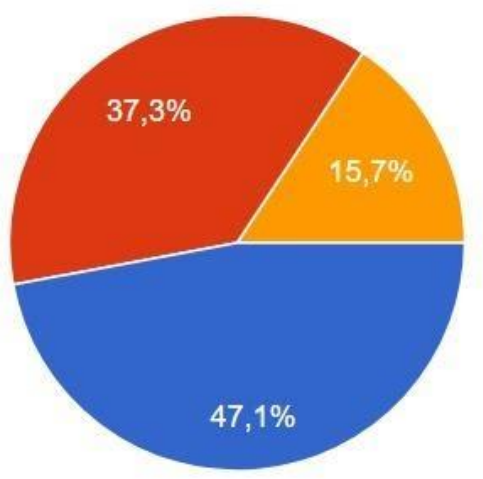

Düşük (Uzaktan eğitimi bu süreçten önce pek bilmiyordum ve kullanmıyordum)

Orta (Uzaktan eğitimi biliyordum ama kullanmıyordum)

Yüksek (Uzaktan eğitimi iyi düzeyde biliyor ve kullanıyordum)

Şekil 4. Katılımcıların Uzaktan Eğitime İlişkin Deneyim ve Kullanım Düzeyleri

Şekil 4.'te de görüleceği üzere araştırmaya katılan velilerin yarıya yakını $(\% 47,1)$ uzaktan eğitimle ilgili geçmiş deneyimlerinin düşük olduğunu dile getirmektedir. Bu kişiler, salgın sürecinden önce uzaktan eğitime dair bilgilerinin olmadığını ve bu eğitim yöntemini kullanmadıklarını ifade etmişlerdir. \%37,3'lük orandaki öğrenci velisi ise, uzaktan eğitime dair deneyim ve kullanım düzeylerini orta seviye olarak nitelemişlerdir. Bu grupta yer alan katılımcılar, uzaktan eğitim süreçleri hakkında bilgi sahibi olduklarını fakat uzaktan eğitim araçlarını kullanmadıklarını belirtmişlerdir. \%15,7'lik dilimde yer alan öğrenci velileri ise uzaktan eğitimi yüksek düzeyde bilen ve aktif bir biçimde kullanan kişilerdir.

\section{Uzaktan Eğitimin Teknik Boyutuna ilişkin Veli Görüşleri}

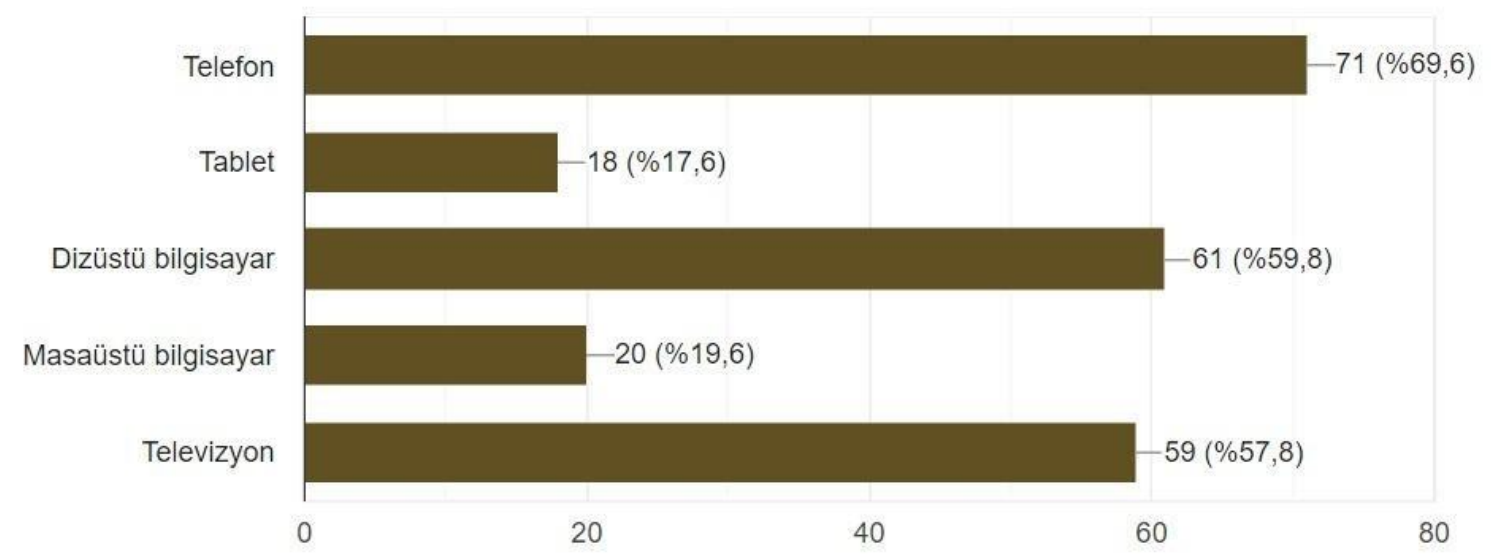

Şekil 5. Velilerin Öğrencilerinin Uzaktan Eğitime Bağlanırken Kullandıkları Araçlar 
Şekil 5.'te öğrenci velileri, öğrencilerinin uzaktan eğitime bağlanırken kullandıkları araçları belirtmektedirler. Bu durum, velilerin, çocuklarının hangi araçları kullandıklarını takip ettiğine işaret etmektedir. Buradan hareketle velilerin uzaktan eğitime yönelik ilgi ve sorumluluk taşıdıkları kanısına ulaşılabilir. Şekil.5 incelendiğinde velilerin uzaktan eğitim ile yürütülen derslere bağlanırken daha çok cep telefonu $(\% 69,6)$, dizüstü bilgisayarı $(\% 59,8)$ ve televizyonu $(\% 57,8)$ tercih ettikleri görülmektedir. Masaüstü bilgisayar $(\% 19,6)$ ve tablet $(\% 17,6)$ aracılığıyla derse bağlanma oranı düşük seviyelerdedir. Bunun sebebini cep telefonları ve dizüstü bilgisayarların daha pratik oluşuyla açıklamak mümkündür. Televizyon seçeneği de rağbet edilen bir araç görünümdedir. Bu durum, internet bağlantısının sorunlu olduğu zamanlarda televizyon yayınının herhangi bir kesintiye uğramamasına ve uzaktan eğitimin ilk döneminde derslerin EBATV üzerinden yayınlanıyor olmasına bağlanabilir. Masaüstü bilgisayar aracılığıyla derse bağlanırken ise mikrofon ve kamera gibi ek donanımlara ihtiyaç duyulması, bu aracın tercih edilmemesini açıklamaktadır.

Şekil 6.'da uzaktan eğitime bağlanırken yaşanan teknik problemlere yer verilmiştir:

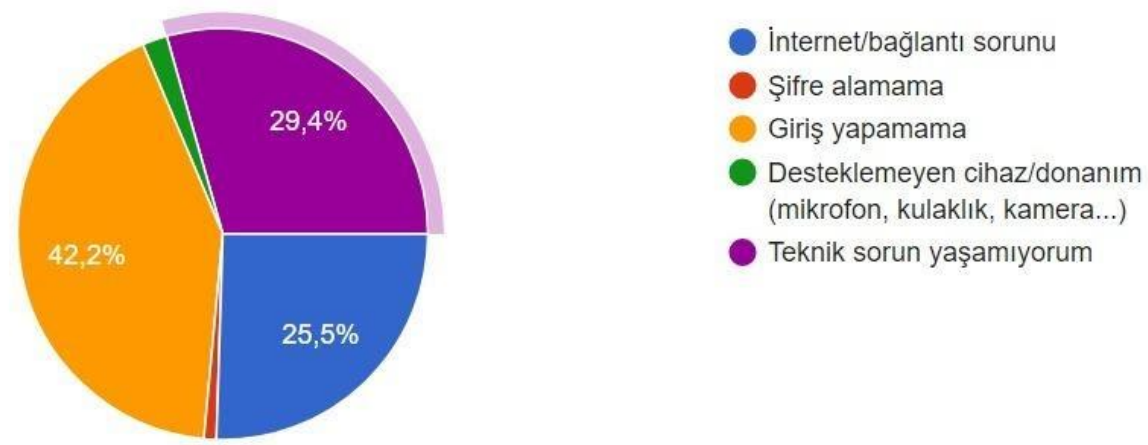

Şekil 6. Uzaktan Eğitime Bağlanırken Karşılaşılan Teknik Aksaklıklar

Şekil 6. incelendiğinde velilerin çocuklarının çeşitli teknik aksaklıklarla karşılaştıkları görülmektedir. Teknik sorun yaşamadığını belirten velilerin oranının \%29,4 $(f=30)$ olduğu dikkate alınınca katılımcıların büyük bir kısmının, \%70,6'nın teknik sorun yaşadıkları ortaya çıkmaktadır. Katılımcılar, çocuklarının 43'ünün (\%42,2) sisteme giriş yapmakta zorlandıklarını; 26'sının $(\% 25,5)$ internet bağlantısının sorunlu olduğunu, 1'inin (\%1) şifre almakta sorun yaşadığını, 2'sinin (\%2) mikrofon, kulaklık ve kamera gibi donanımların arızalı olduğunu ifade etmişlerdir. Velilerin, çocuklarının yaşadıkları teknik sorunların farkında oldukları anlaşılmaktadır.

\section{Uzaktan Eğitimin Öğrenci Motivasyonuna Katkısına i̇lişkin Veli Görüşleri}

Araştırmaya katılan öğrenci velilerinden uzaktan eğitimin öğrenci motivasyonuna etkisini 1'den 5'e kadar puanlandırmaları istenmiştir. Velilerin uzaktan eğitimin öğrencilerin motivasyonuna katkı düzeyi ilgili görüşleri Şekil 7.'de belirtilmiştir:

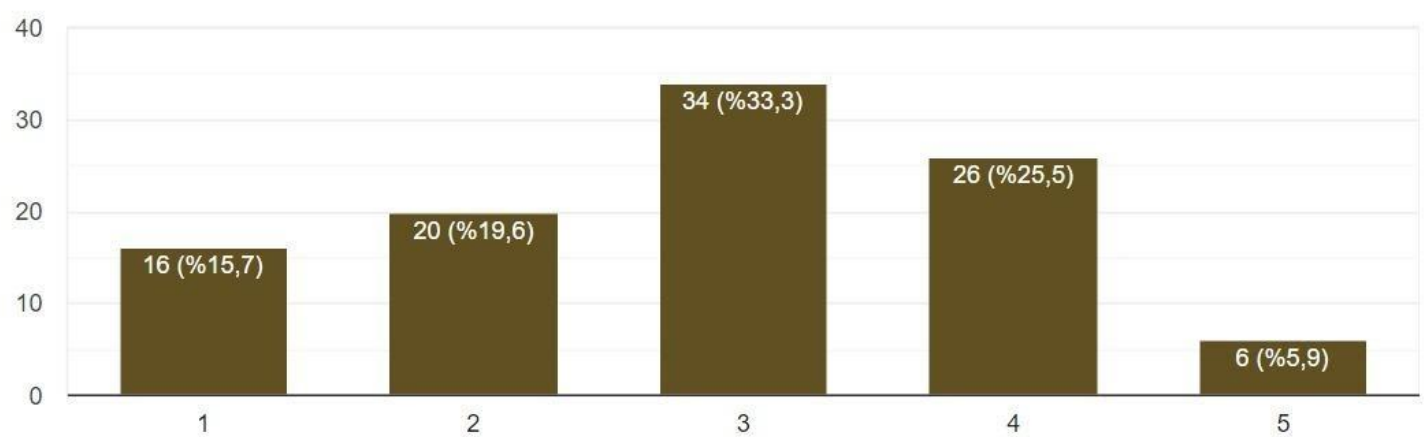

Şekil 7. Uzaktan Eğitimin Öğrencilerin Motivasyonuna Katkı Düzeyi Hakkındaki Veli Görüşleri 
Şekil 7. incelendiğinde araştırmaya katılan velilerin uzaktan eğitimin öğrenci motivasyonuna katkı düzeyine ilişkin görüşlerinin çeşitlilik gösterdiği görülmektedir. Katılımcıların 3'te 1'i $(\% 33,3)$ uzaktan eğitimin öğrenci motivasyonuna orta düzeyde katkı sağladığını belirtmektedir. Katıımcıların 4'te 1'i bu katkının yüksek düzeyde olduğunu belirtirken 5'te 1'i düşük olduğunu, \%15,7'si çok düşük, $\% 5,9^{\prime} u$ ise çok yüksek olduğunu ifade etmiştir. Öğrenci velilerinin, uzaktan eğitim ortamlarının çocuklarını orta düzeyde etkilediğini belirtmesi, öğrencilerin dijital bir çağda doğmuş olmaları ve teknolojik araç gereçlere aşina olmaları ile ilişkilendirilebilir. Uzaktan eğitimde kanal olarak kullanılan televizyon, tablet, telefon ve bilgisayar gibi aletler, çocukların ilgisini çekmiş olabilir.

\section{Uzaktan Eğitimin Öğrencilerin Sosyalleşmesine Katkısına ilişkin Veli Görüşleri}

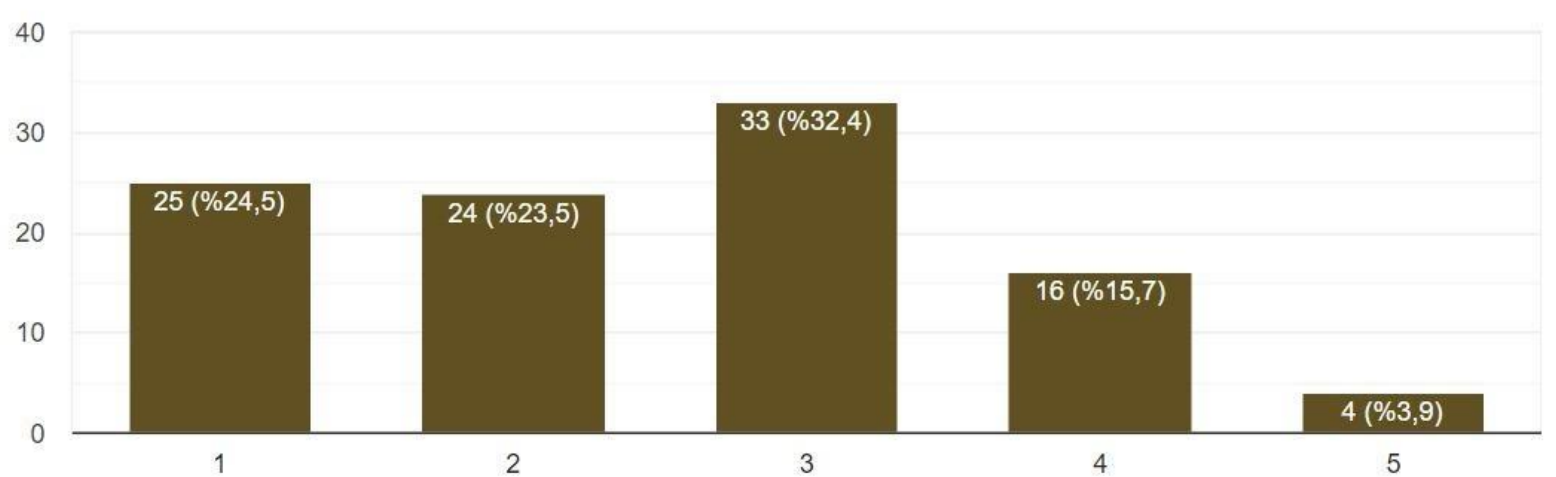

Şekil 8. Uzaktan Eğitimin Öğrencilerin Sosyalleşmesine Katkı Düzeyi Hakkındaki Veli Görüşleri

Velilere, uzaktan eğitimin öğrencilerin sosyalleşmesine katkısı hakkındaki görüşleri sorulmuş, onlardan bu katkıyı 1'den 5'e puanlamaları istenmiştir. Velilerin \%32,4'ü uzaktan eğitimin orta düzey seçeneğini işaretlemişlerdir. Sosyalleşmeye katkı düzeyini 1 veya 2 puanla düşük olarak puanlayan velilerin toplam oranının (\%48) 4 veya 5 puanla yüksek olarak puanlayan velilerin toplam oranından $(\% 19,6)$ çok daha fazla olması göze çarpmaktadır. Herhangi bir fiziksel sınıf ortamı olmadan teknolojik araç gereçler vasıtasıyla uzaktan eğitime bağlanan çocukların geleneksel olarak algılanan bir sosyalleşme imkânı yakalayamamaları beklenen bir durumdur. Bu duruma istinaden öğrenci velilerinin sosyalleşmeye katkı boyutunda düşük puan yönünde görüş belirttikleri düşünülmektedir.

\section{Uzaktan Eğitimin Öğrencilerin Dikkat Düzeylerine Katkısına İlişkin Veli Görüşleri}

Alan yazında ifade edildiği üzere uzaktan eğitim ortamlarının öğrenciler için dikkat çekici olduğu kadar zaman zaman da dikkatlerini dağıtan unsurlar barındırdığı için öğrenci velilerine, uzaktan eğitim sürecinin çocuklarının dikkat düzeylerine katkısı sorulmuştur. Alınan cevaplar, aşağıdaki şekilde gösterilmektedir:

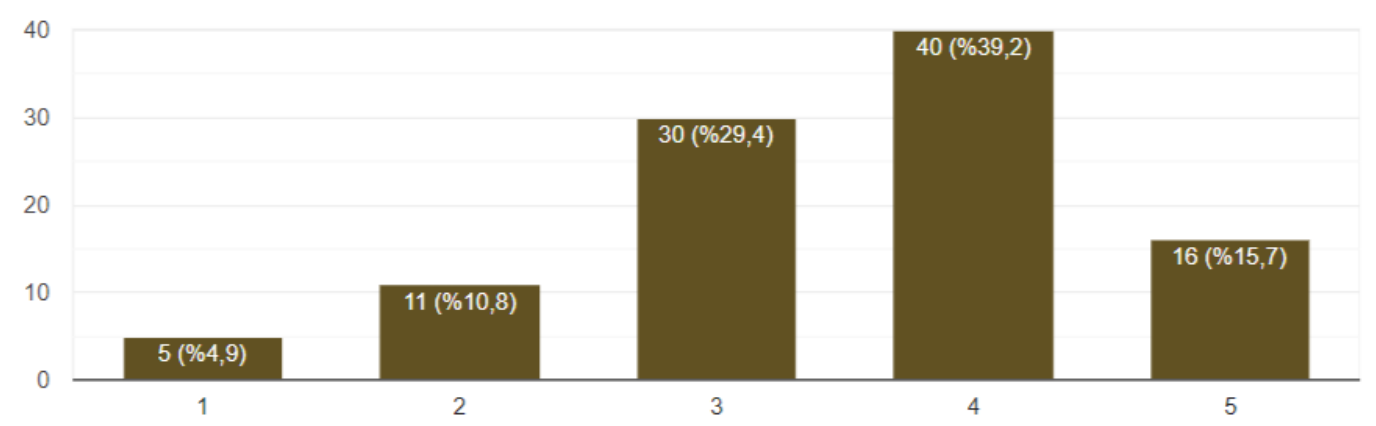

Şekil 9. Velilerin Uzaktan Eğitimin Öğrencilerin Dikkat Düzeyine Katkısı Hakkındaki Görüşleri 
Yukarıdaki şekil incelendiğinde en çok tercih edilen seçeneğin \%39,2 oranla 4, yani yüksek olduğu görülür. Orta ifadesine karşılık gelen 3 puan da velilerin \%29,'ü tarafından işaretlenmiştir. Öte yandan velilerin çok az bir kısmı, uzaktan eğitimin çocukların dikkatine düşük düzeyde katkı sağladığını belirtmektedir. Uzaktan eğitimin öğrencilerin dikkat durumuna genel olarak orta ve yüksek düzeyde katkı sağladığı görüşü, teknolojik araç gereçlerin Z kuşağında bulunan öğrencilerin dikkatini çekmesi ve bu durumun veliler tarafından gözlemlenmesinin sonucu olarak okunabilir.

\section{Uzaktan Eğitimin Çocuklarının Temel Dil Becerilerine Katkısına ilişskin Veli Görüşleri}

Türkçe dersleri, bilgiden ziyade beceri odaklı derslerdir. Türkçe dersinin en temel amaçlarından biri dört temel dil becerisi olarak bilinen dinleme, konuşma, okuma ve yazma alanlarını geliştirmektir. Bu sebeple velilere, uzaktan eğitim sürecinin çocuklarının temel dil becerilerini ne ölçüde geliştirdiği sorusu yöneltilmiştir. Her bir beceri alanı için ayrı soru sorularak daha detaylı bir inceleme yapılmak istenmiştir. Bu esnada becerilerin bireyler tarafından edinilme sırası gözetilmek suretiyle sorular dinleme, konuşma, okuma ve yazma şeklinde art arda sorulmuştur. Elde edilen veriler, aşağıda şekiller aracılığıyla aktarılmıştır.

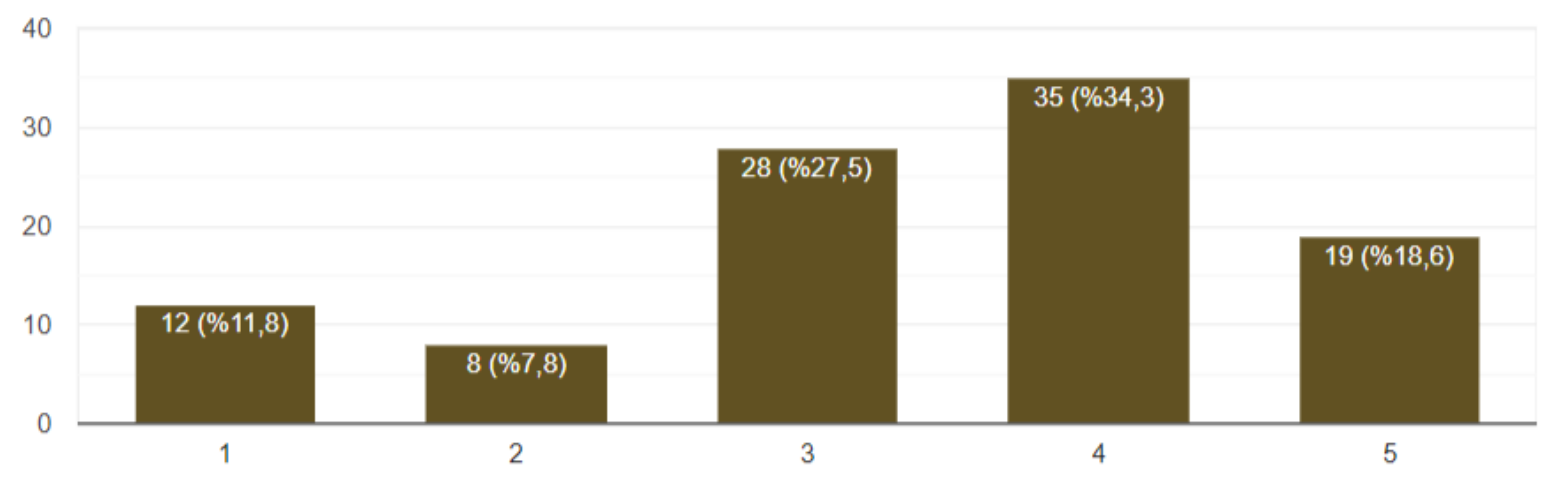

Şekil 10. Velilerin Uzaktan Eğitimin Dinleme Becerisine Katkı Düzeyi Hakkındaki Görüşleri

Şekil 10. incelendiğinde velilerin genel itibariyle uzaktan eğitimin çocukların dinleme becerisine yüksek düzeylerde katkı sunduğu yönünde görüş belirttikleri görülmektedir. Araştırmaya katılan velilerin $\% 34,3$ 'ünün 4 puanla yüksek düzey ve $\% 27,5$ 'inin 3 puanla orta düzey seçeneğini işaretlemişlerdir. Uzaktan eğitimde öğretmenin dersi sunması esnasında öğrencilerin dinleyici konumunda bulunmaları durumunu gözlemleyen velilerin bu kanıya varmış oldukları düşünülebilir. Çok düşük ifadesine karşılık gelen 1 puan ve düşük ifadesini karşılayan 2 seçeneklerini işaretleyen katılımcılar ise düşük oranlardadır (toplam \%19,6).

Araştırmaya katılan öğrenci velilerinin uzaktan eğitimin okuma becerisine katkı düzeyi ile ilgili görüşleri Şekil 11.'de belirtilmiştir:

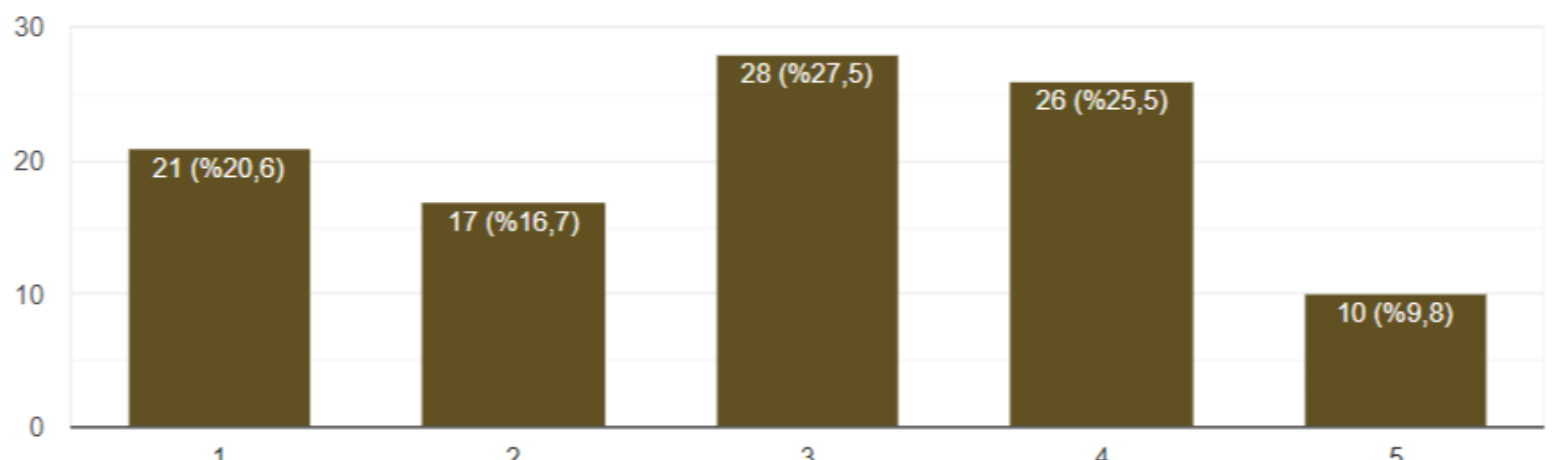

Şekil 11. Velilerin Uzaktan Eğitimin Okuma Becerisine Katkı Düzeyi Hakkındaki Görüşleri 
Şekil 11. incelendiğinde öğrenci velilerinin, uzaktan eğitimin okuma becerisine katkısını orta düzeyde değerlendirdikleri görülmektedir. Bu şekildeki en yüksek değer olarak velilerin $28^{\prime} i(\% 27,5)$ orta düzeyde katkı sunduğunu düşünmektedir. Öte yandan araştırmaya katılan velilerden 21'nin $(\% 20,6)$ uzaktan eğitimi okuma becerisini geliştirme düzeyini çok düşük olarak ifade etmeleri, dikkat çeken bir bulgudur. Geleneksel sınıf ortamının bulunmayışı, velilere okumanın yeterince geliştirilemediğini düşündürmüş olabilir. Okuma eğitimi açısından dikkate alınması gereken bir bulgudur. Bu bulgunun ekran okumayla ilişkisi de araştırılmaya değer bir alan olarak göze çarpmaktadır.

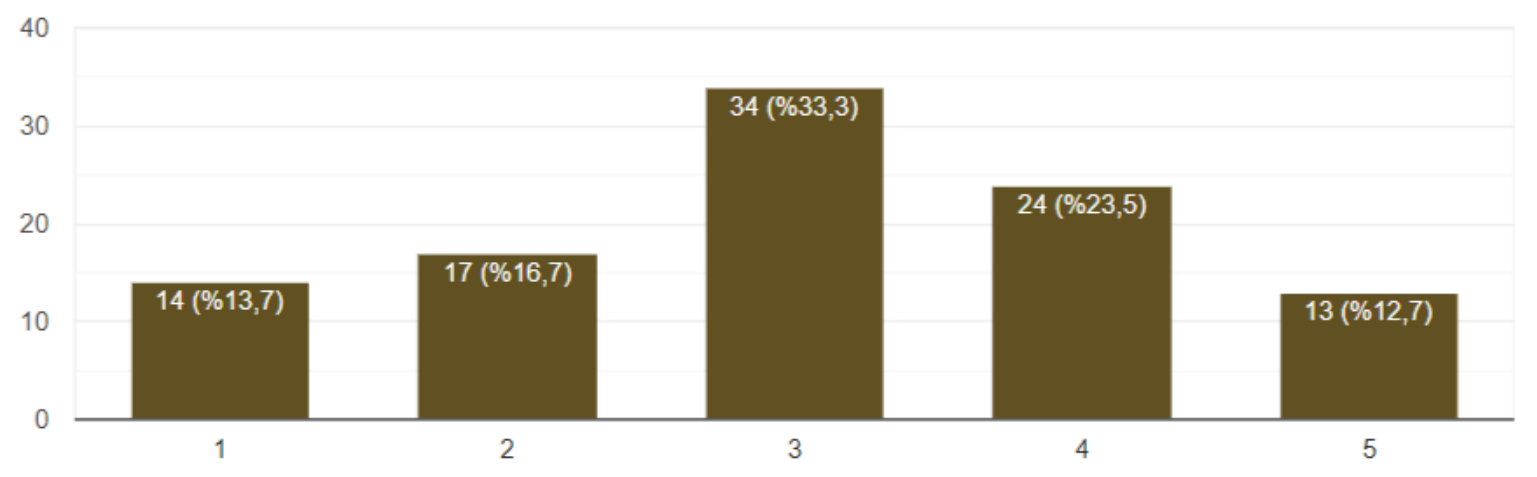

Şekil 12. Velilerin Uzaktan Eğitimin Konuşma Becerisine Katkı Düzeyi Hakkındaki Görüşleri

Şekil 12. incelendiğinde velilerin uzaktan eğitimin çocuklarının konuşma becerisine genel katkısını 3 puan $(\% 33,3)$ ve 4 puan $(\% 23,5)$ şeklinde değerlendirdikleri görülmektedir. Uzaktan eğitimde öğrencilerin söz hakkı alıp derse katılma olanaklarının bulunması, velilerin konuşma becerisine ilişkin orta düzey görüşünde olmalarına yol açmış olabilir.

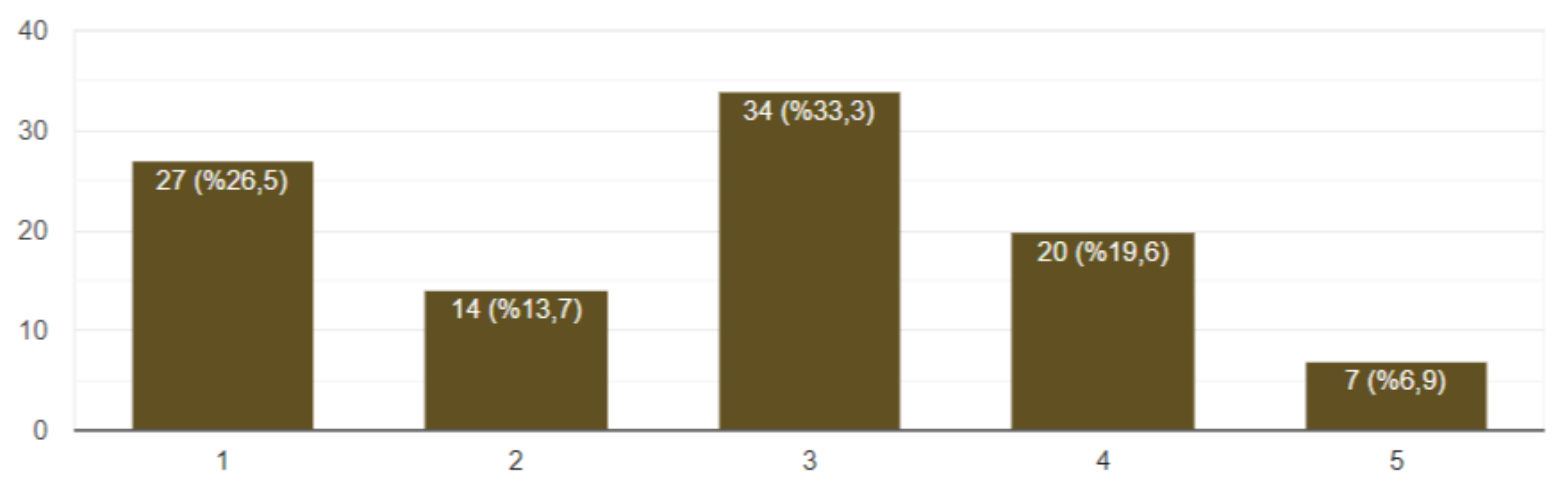

Şekil 13. Velilerin Uzaktan Eğitimin Yazma Becerisine Katkı Düzeyi Hakkındaki Görüşleri

Şekil 13.'e bakıldığında 3 puan cevabının oransal olarak yüksek olduğu $(\% 33,3)$ görülmektedir. Velilerin 3'te 1'i, orta düzey katkı sunma seçeneğini işaretlemiştir. Öte yandan velilerin 4'te 1'i, uzaktan eğitim sürecinde çocuklarının yazılı anlatım becerilerinin çok düşük bir hızda geliştiğini düşünmektedir. Uzaktan eğitimde sözlü anlatım becerilerinin daha çok kullanılması, özellikle de televizyonun kullanıldığı durumlarda yazma becerisi için gereken öğretmen-öğrenci etkileşimi ortamının oluşmaması, bu duruma neden olmuş olabilir.

\section{Uzaktan Eğitim Sürecinde Ödev Durumu ve Takibine ilişkin Veli Görüşleri}

Öğrenci velilerine, uzaktan eğitim sürecinde ödev durumu ve takibine dair sorular sorulmuştur. Alınan cevaplar, katılımcıların genel itibariyle ödev durumunun verimsiz olduğunu ve takibinin zor olduğunu düşündükleri ortaya çıkarmaktadır. ÖV46, "Bence bu pek de iyi bir ödev verme şekli değil 
çünkü öğrencinin ödevi yapıp yapmadığını bilemeyiz. Belki cevap anahtarından da bakıyor olabilir. Yüz yüze olsaydı kimin ödevi yapıp yapmadığını ya da cevap anahtarına bakıp bakmadığını anlayabilirdik." sözleriyle uzaktan eğitimde verilen ödevlerin takip edilmesinin güçlüğüne dikkat çekmektedir. "Ödev takibi pek iyi değil çünkü hocalar kimin neyi yaptığını göremiyor ve çocuklar henüz okullar açılmıyor diye ödevleri yapmıyor." diyen ÖV54, ödev takibi konusundaki olumsuzluğun öğrencileri ödev yapmamaya sevk ettiğini belirtmektedir. ÖV35 ise "Ödevler online olunca öğretmenin takibi daha kolaydır. Ama başkasının yapma ihtimali de olabilir." sözleriyle dikkat çekmektedir. Diğer velilerin de ödevlere ilişkin belirttikleri olumsuz görüşlerden bazıları aşağıda sıralanmıştır:

"Çok verimli olmadığını düşünüyorum." (ÖV85)

"Ödev verilebilir fakat takibi zordur." (ÖV39)

"Ödev yaptırmak ve takibi gerçekten çok zor." (ÖV15)

"Ödevde takip de yok ne yazık ki çocuklar yüz yüze eğitimdeki kadar ciddiye almıyorlar dersleri." (ÖV95)

\section{Uzaktan Eğitime Devam Edilmesiyle İlgili Veli Görüşleri}

Velilerin uzaktan eğitime ilişkin memnuniyet düzeylerini öğrenmek ve görüşlerini irdelemek adına onlara, önümüzdeki dönem uzaktan eğitim sistemine devam edilip edilmemesi konusundaki tercihleri sorulmuştur. Bu soru için velilere 3 seçenek sunulmuş, "Evet, isterim. Seneye tamamen uzaktan eğitim olsun.", "Kısmen isterim. Uzaktan ve yüz yüze eğitim birlikte kullanılsın." ve "Hayır, istemem. Yüz yüze eğitime geri dönülsün." ifadelerinden birini seçmeleri istenmiştir. Velilerden alınan cevaplar, aşağıdaki şekli meydana getirmiştir:

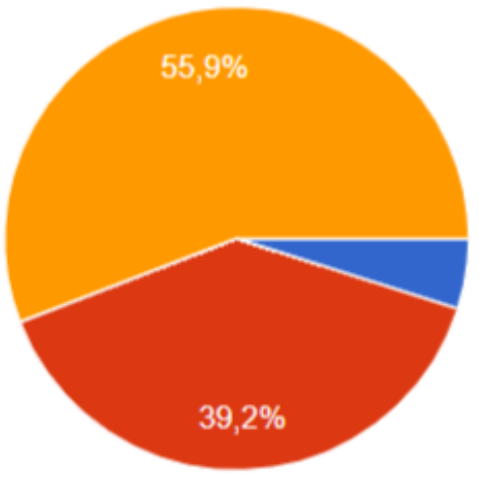

Şekil 14. Uzaktan Eğitime Devam Edilmesi ile ilgili Veli Görüşleri
Evet, isterim. Seneye tamamen uzaktan eğitim olsun.

Kısmen isterim. Uzaktan ve yüz yüze eğitim birlikte kullanılsın.

Hayır, istemem. Yüz yüze eğitime geri dönülsün.

Şekil 14. incelendiğinde velilerin büyük bir kısmının $(\% 55,9)$ uzaktan eğitimin devam etmesini istemedikleri ve yüz yüze eğitime geri dönülmesini tercih ettikleri görülmektedir. Uzaktan ve yüz yüze eğitim yöntemlerinin bir arada kullanılması gerektiğini düşünenlerin oranı da $(\% 39,2)$ azımsanmayacak ölçüdedir. Çalışmaya katılan 102 veliden yalnızca 5’i $(\% 4,9)$ gelecek dönem uzaktan eğitimle derslerin devam etmesini istediğini belirtmiştir. Bu 5 velinin uzaktan eğitime dair bilgi sahibi olduğu ve salgından önce uzaktan eğitim deneyimlerinin bulunduğu araştırmanın bulguları arasındadır. Eğitim sürecinin geleneksel bir biçimde yüz yüze olarak devam etmesini tercih eden velilerin büyük bir bölümü ise uzaktan eğitime dair bilgi ve deneyim sahibi olmadıklarından uzaktan eğitimin teknik, psikolojik ve sosyal boyutlarında sorunlarla karşılaşmışlardır. Uzaktan eğitime devam edilmesini istemeyen bazı velilerinin görüşleri şu şekildedir:

"Artık yüz yüze eğitime geçilsin." (ÖV29)

"istemiyorum." (ÖV78)

"Olumlu bulmuyorum." (ÖV56)

Katılımcılara uzaktan eğitimi tercih etmemelerinin sebepleri sorulduğunda yüz yüze eğitime nazaran uzaktan eğitimin eksilerini sıraladıkları görülmüştür. Katılımcılar "Çok faydalı olmuyor. " 
(ÖV52), "Yüz yüze eğitim kadar etkili olduğunu düşünmüyorum." (ÖV72) ve "Yüz yüze eğitimin daha sağlıklı olduğunu düşünüyorum" (ÖV6) ve "Okulda yüz yüze olması daha iyi olacaktır." (ÖV68) şeklinde fikirlerini belirtmişlerdir.

"EBA uzaktan eğitimde canlı derse katılım yapamıyoruz." diyen ÖV17, yaşanan teknik aksaklıklardan ötürü bu yönde görüş belirtmektedir. "EBA üzerinden bağlantı sıkıntısı yaşıyoruz. Zoom dan devam etse." diyen ÖV73, "EBA'dan hiç canlı ders yapılamadı bence uzaktan eğitim sıkıntıı." diyen ÖV33 ve "Uzaktan eğitim EBA üzerinden değil de Zoom'dan daha iyi olduğunu düşünüyorum" diyen ÖV84 ise EBA yerine Zoom'un kullanıldığı durumlarda daha az teknik sorunla karşılaşıldığını dile getirmektedir.

"Zorunluluk olmasaydı uzaktan eğitimin yürütülmesini istemezdim. Çünkü örgün ve yüz yüze eğitim daha verimli olmakta." diyen ÖV32 ve "Bu süreçte buna mecburuz. Bir şikayetimiz yok. Ancak uzaktan eğitim devamlı veya kalıcı olmamalı. Verimsiz çünkü öğrenme düzeyi çok düşük. Şu etapta uzaktan, bu şekilde devam etmeli okullar açılsa da ben göndermem. Önce sağlık!" sözlerini sarf eden ÖV7 salgın döneminde yaygın bir biçimde başvurulan bir yöntem olan uzaktan eğitimin, yüz yüze eğitim kadar etkili olmasa da zorunluluktan ötürü halkın sağlığının korunması adına tercih edildiğini dile getirmektedir.

Öğrenci velilerinden bazıları ise uzaktan eğitim ve yüz yüze eğitimin bir arada yürütülmesi gerektiğini belirtmişlerdir. ÖV95, "Uzaktan eğitim ve yüz yüze eğitim bir arada giderse o zaman başarılı olacağını düşünüyorum ama tek taraflı olduğunda belli bir süre sonra çocuklar ciddiyetini kaybediyor." diyerek hibrit eğitimin, iki tür eğitimin de avantajlarını bir araya topladığını ifade etmektedir. "Bana göre eğitimi çeşitlendirmek güzel. Muhakkak teknoloji eğitimin içinde yer almalı. Ama sosyal bir varlık olan bizlerin kaynaşmaya yüz yüze iletişimin sıcaklığını hissetmeye ihtiyacımız var. Yan bir yöntem olabilir." şeklinde görüş bildiren ÖV35 ve "Türkçe dersi uzaktan eğitimle yapılabilir ancak birebir eğitimle olduğu kadar etkili olmayacağını düşünüyorum. Çocukların öğretmenleriyle ve arkadaşlarıyla kurmuş olduğu duygusal bağ adaptasyon için çok önemli." diyen ÖV85, uzaktan eğitime karşı olmadıklarını ancak teknolojik araç gereçlerin sosyal etkileşim ortamı yaratma konusunda sınıf içi kadar başarılı olamadığını belirtmektedir.

Velilerden bazıları, uzaktan eğitim-yüz yüze eğitim ayrımı hususunda Türkçe dersleri özelinde görüş bildirmekte ve uzaktan eğitimin genel itibariyle Türkçe derslerinin etkili bir biçimde işlenişine imkân tanımadığını belirtmektedirler. "Türkçe eğitim uzaktan olmuyor ne yazık ki. Çocukların erim dönemine denk gelen ortaöğretim zaten kişilik karmaşası yaşayan yüzlerce çocuğu bir cam ekran karşısından düzenli ders çalışmaya teşvik etmek hiç de teşvik edici değil." diyen ÖV20 ve "Çocuğumun dinleme becerisinin gelişmesi açısından olumlu buluyorum. Görsel algısının gelişmesine de önemli katkıları var. Sonuçta Türkçe dersi sözel bir ders. Ancak sınıftaki öğretmenin yerini hiçbir şey dolduramaz." diyen ÖV4 bu duruma örnek olarak verilebilir. ÖV54, "Uzaktan eğitim sürecinde yapılan Türkçe dersleri gayet verimli." diyerek durumdan memnuniyetini dile getirmiş, ÖV51 de "Özellikle EBA'nın Türkçe dersinin verimli olduğunu düşünüyorum." sözleriyle işitsel görsel araçların Türkçe dersinin daha etkili bir biçimde işlenmesine katkı sağladığını belirtmektedir. "Sadece Türkçe değil bütün derslerin direkt olarak öğretmenden sınıfta dinlemeleri daha iyi diye düşünüyorum." diyen ÖV45 ise Türkçe dersleri özelinde değil, diğer dersler açısından da yüz yüze eğitimin daha yararlı olduğunu düşünmektedir.

Velilerden çok az bir bölümü, yüz yüze eğitim yerine uzaktan eğitim ile devam edilmesini istediklerini belirtmişlerdir. ÖV46, "Yani zaten virüs bitesiye kadar tüm dersler uzaktan eğitim ile devam edecek. Ben kızımdan duyduğum kadarıyla hep test çözdüklerini öğrendim. Bu yüzden uzaktan eğitimin Türkçe dersine pek bir etkisi olmadığını söyleyebilirim. Çünkü öğrenciler okulda da test çözüyorlardı. Hatta uzaktan eğitim daha iyi oldu çünkü öğrenciler canlı dersteyken birbirleri ile konuşamazlar. Ya da gizlice iş çeviremezler." diyerek uzaktan eğitimin artılarına dikkat çekmiştir. ÖV2 de "Gördüğüm kadarıyla daha eğlenceli ve istekli geçiyor, devam edebilir." sözleriyle uzaktan eğitimin çocuklar için yüz yüze eğitime göre daha ilgi çekici ve eğlenceli geçtiğine ilişkin gözlemlerini paylaşmaktadır. 


\section{Tartışma, Sonuç ve Öneriler}

Covid-19 salgınının patlak vermesiyle birlikte uzaktan eğitime geçilmiş, eğitim sistemimiz için yeni olan bu durum karşısında uzaktan eğitime dair birçok çalışma gerçekleştirilmiştir. Alan yazında görülen bir eksikliği tamamlamaya yönelik bu çalışmanın amacı, uzaktan eğitim sürecine ilişkin veli görüşlerini ortaya çıkarıp incelemektir. Araştırma kapsamında Manisa ilinde ikamet etmekte olan toplam 102 öğrenci velisine ulaşılmıştır. Velilere uzaktan eğitimle ilgili karşılaşılan teknik aksaklıklar, motivasyon, sosyalleşme, dikkat, temel dil becerileri, ödev durumu ve takibi, eğitim verimliliği gibi boyutlarda sorular yöneltilmiştir.

Uzaktan eğitimin teknik boyutunda, kullanılan araç-gereç, uzaktan eğitime dair bilgi ve deneyim düzeyi, teknik problemlerle karşılaşma durumları araştııılmıştır. Uzaktan eğitime bağlanırken kullanılan araç-gereçler cep telefonu $(\% 69,6)$, dizüstü bilgisayarı $(\% 59,8)$, televizyonu $(\% 57,8)$, masaüstü bilgisayar $(\% 19,6)$ ve tablet $(\% 17,6)$ şeklindedir. Benzer bir şekilde Aksoğan'ın $(2020)$ çalışmasında uzaktan eğitime bağlanırken katılımcıların \% 70'inin telefon, \% 28'inin bilgisayar, \% 1,4'ünün ise tablet kullandığı tespit edilmiştir. Bu bakımdan bu çalışmayla Aksoğan'ın (2020) araştırması birbiriyle örtüşmektedir.

Araştırmaya katılan velilerin büyük çoğunluğu $(\% 70,6)$ uzaktan eğitim sürecinde teknik problemlerle karşılaştıklarını ifade etmektedir. Ayrıca katılımcıların salgın öncesi dönemde genel olarak uzaktan eğitimi bilmedikleri veya bilip kullanmadıkları sonucuna ulaşılmışır. Velilerin sadece $\% 15,7$ 'sinin daha önceden uzaktan eğitim araçlarına dair bilgi ve deneyim sahibi oldukları bulgulanmıştır. Geri kalan \%84,3'lük çoğunluğun uzaktan eğitime ilişkin bilgi ve uygulama düzeyleri düşüktür. Buradan hareketle uzaktan eğitime dair bilgi ve deneyim sahibi olma faktörünün yaşanacak aksaklıkları azalttığı ve oluşabilecek sorunların çözümünde etkili olduğu sonucuna ulaşılabilir. Teknik problemler yaşama riski, uzaktan eğitim yönteminin sahip olduğu dezavantajlarından biri olarak görülmektedir (Altıparmak, Kurt ve Kapıdere, 2011). Eğitimin teknolojik araç-gereçlere dayalı bir biçimde yürütülmesi, bu tür riskleri beraberinde getirmektedir. Telli Yamamoto ve Altun (2020) deneyim ve bilgi sahibi olmayan kullanıcıların uzaktan eğitim araç ve ortamlarından uzak durmak biçiminde tepki verdiğini hatırlatmaktadır.

Velilerin uzaktan eğitim bilgi ve deneyim düzeylerinin birbirinden farklı olması, uygulamada da farklııkların oluşmasına yol açmıştır. Bir diğer deyişle velilerin fırsatlara eşit bir biçimde erişmediği görülmektedir. Alan yazında bu farklar "dijital uçurum" olarak tanımlanmaktadır (OECD, 2001; Öztürk, 2005). Sosyoekonomik nedenler ve kuşak farklılıkları sebebiyle meydana gelen bu uçurumun yerel, ulusal ve küresel boyutlarda birçok problemi beraberinde getirdiği dile getirilmiştir (Öztürk, 2002). Veli, öğretmen ve öğrencilerin dijital uçurum dolayısıyla yaşadıkları sorunlar ve bunların meydana getirdiği fırsat eşitsizliklerini gidermek adına altyapı güçlendirme ve bilgilendirme gibi çalışmaların yapılması gerektiği vurgulanmaktadır (Sezgin ve Fırat, 2020; Başaran vd., 2020; Öztürk, 2005).

Uzaktan eğitimde öğrenci motivasyonu boyutunda, veli görüşlerine göre öğrencilerin orta düzeyde motive oldukları tespit edilmiştir. Uzaktan eğitimin öğrenci motivasyonuna etkisinin farklı araştırmalarda değişik düzeylerde olduğu tespit edilmiştir. Dinçer (2016), uzaktan eğitimin zaman ve mekân sınırlaması olmamasının öğrencinin motivasyonunu yüksek tutmada etkili olduğunu belirtirken Altıparmak ve diğ. (2011) ise teknik problemlerin ve bireysel çalışma disiplini eksikliğinin uzaktan eğitimde motivasyonu düşüren ana etmenler olduğunu ifade etmektedir. İnci Kuzu (2020), EBA TV'ye ilişkin veli algısının araştırıldığı çalışmasında öğrencilerin velileriyle birlikte dersleri takip ettiklerini, derse etkin bir biçimde katılmanın ve arkadaşlarıyla etkileşim hâlinde olmanın öğrencileri motive ettiğini, yaşanan tüm olumsuzluklara rağmen motivasyon düzeyinin süreç boyunca düşmediğini kaydetmektedir. Yılmaz, Mutlu ve Doğanay (2020) ise öğretmenlerin uzaktan eğitim konusunda yeterlilik sahibi olmamaları, öğrencilerin de teknik sorunlar yaşamaları ve ders takibinin zor olması nedeniyle öğrenci motivasyonunun düşük olduğunu belirtmektedir. Wheeler (2002), uzaktan eğitimde öğrenci motivasyonunun yüz yüze eğitime kıyasla daha düşük olduğunu aktarmaktadır.

Sosyalleşme boyutunda, veli görüşlerine göre uzaktan eğitimin öğrencilerin sosyalleşmesine orta ve düşük düzeylerde katkı sağladığı sonucuna ulaşılmıştır. Yüz yüze gerçekleşmeyen ve internet bağlantısı aracılığıyla ekranlar üzerinden yapılan uzaktan derslerde etkileşim unsurunun düşük düzeylerde kaldığı farklı araştırmacılar tarafından vurgulanmıştır (Akyürek, 2020; Elcil ve Şahiner, 2014; 
Ustati ve Hassan, 2013). Etkileşimin düşük düzeyde kalması, öğreniciler arasında tedirginliğin oluşmasına yol açmakta ve öğrenme sürecini olumsuz etkilemektedir (Duran, 2020).

Dikkat boyutunda, veliler uzaktan eğitimin öğrencilerin dikkat süreçlerine yüksek düzeyde katkı sağladığını ifade etmektedir. Elcil ve Şahiner (2014), uzaktan eğitimin üniversite öğrencilerinin dikkatini olumsuz etkilediği sonucuna ulaşmıştır. Çalışmamızla farklılık arz eden bu sonuç, araştırma yapılan grubun özellikleriyle ilgili olabilir. Ayrıca çalışmalar arasındaki zaman farkı ile üniversite ve ortaokul öğrencilerinin teknolojiye ilişkin tutum farklılıklarının da bu çalışmada Elcil ve Şahiner'in (2014) araştırmasından farklı bulgulara ulaşılmasında etkili olduğu düşünülmektedir.

Temel dil becerileri boyutunda, veli görüşleri doğrultusunda uzaktan eğitim, öğrencilerin dinleme becerilerine yüksek, konuşma becerilerine orta, okuma becerilerine orta ve yazma becerilerine düşük düzeylerde katkı sağlamaktadır. Bayburtlu'nun (2020) çalışmasına katılan Türkçe öğretmenlerinin görüşlerine göre, uzaktan eğitim sürecinde dinleme etkinliklerinin verimli bir biçimde yapılamadığı ortaya çıkmıştır. Bu sonuç ile araştırmamızın sonuçlarının birbirinden farklı olduğu görülmektedir. Bu durum, eğitim-öğretim sürecinin farklı unsurları olan öğrenci ve velilerin, uzaktan eğitimin dinleme becerisine katkısı bakımından birbirinden farklı görüşlere sahip olduğu şeklinde anlaşılabilir. Dinleme, anne karnından başlayan, bu yüzden kendiliğinden geliştiği düşünülen, dolayısıyla inmal edilen bir beceri alanı olarak bilinmektedir (Doğan, 2010). Burada ortaya çıkan görüş farklarının dinlemeye ilişkin algılardan kaynaklandığı söylenebilir.

Velilere göre yazma becerisi, uzaktan eğitimde en az desteklenen beceri alanıdır. En son edinilen ve en zor geliştirilen alanlardan biri olan yazma becerisi, bünyesinde birçok üst bilişsel işlem ve süreci barındırmaktadır (Akyol, 2016; Göçer, 2010). Karakuş ve diğ. (2020) çalışmasında da öğretmen adaylarının yarısından fazlası $(\% 54,3)$ uzaktan eğitimde yazma becerisinin çok düşük düzeyde geliştiğini vurgulamaktadır. Bu bakımdan bu iki çalışmanın sonuçlarının benzerlik gösterdiği söylenebilir.

Öğrenci velileri, konuşma becerisinin uzaktan eğitimle orta düzeyde geliştirildiğini düşünmektedir. Karakuş ve diğ. (2020), uzaktan eğitimle ilgili öğretmen görüşlerine başvurdukları çalışmalarında katılımcıların çoğunluğunun konuşma becerisinin uzaktan eğitimin konuşma becerisine düşük düzeyde katkı sağladığını düşündükleri saptanmıştır. Çalışmanın katılımcıları olan öğrenci velileri, uzaktan eğitimde en çok kullanılan dinleme ve konuşma eylemlerini göz önüne alarak bu yönde görüş belirtmiş olabilir. Öte yandan dil becerileri anlamında daha donanımlı olan Türkçe öğretmeni adaylarının, uzaktan eğitimin konuşmaya katkı düzeyini bu şekilde değerlendirmiş oldukları düşünülmektedir.

Ödev durumu ve takibi boyutunda, velilere göre uzaktan eğitim sürecinde ödevler verimsiz etkinlikler olup takibi zor bir husus olarak görülmektedir. Başaran ve diğ. (2020), uzaktan eğitimde ödevlerin olmamasının hem avantaj hem de dezavantaj olarak görüldügünü ifade ederek ilgi çekici ve geliştirici ödevler vermek suretiyle bu çelişkili durumun ortadan kaldırılabileceğini belirtmektedir. İnci Kuzu'nun (2020) araştırmasında velilerin çok küçük bir bölümü öneri olarak $(\% 4,7)$ öğrencilere ödev verilmesi gerektiğini dile getirmektedir. Bu bakımdan bu çalışmayla araştırmamızın sonuçları benzerlik göstermektedir. Bayburtlu'nun (2020) çalışmasında ödevlendirme sisteminin olmaması hususunun anne babaları çalışan öğrenciler için ödev takibi açısında zorluk oluşturduğu belirtilmektedir.

Uzaktan eğitime devam isteği boyutunda, öğrenci velilerinin çoğunluğunun $(\% 55,9)$ uzaktan eğitimin önümüzdeki dönem devam etmesini istemedikleri, \%39,2'sinin ise hibrit diye tabir edilen sisteme geçilmesini istedikleri bulgusuna ulaşılmıştır. Uzaktan eğitimin bu hâliyle devam etmesini isteyenlerin oranı $(\% 4,9)$ ise oldukça düşük kalmıştır. Öğrenci velileri, hâlihazırda etkisini devam ettiren pandemi şartlarında uzaktan eğitimin can sağlığının korumak için alınan önemli bir tedbir olduğunun bilincindedir. Aynı zamanda veliler, uzaktan eğitim yönteminin yüz yüze eğitime göre bazı dezavantajları bulunduğunun da farkındadır. Yapılan bir başka çalışmada (Aksoğan, 2020) katılımcılar, uzaktan eğitimin yüz yüze eğitimi tam anlamıyla karşılamadığını ancak bu dönemde geçici bir süreliğine eğitime destek olmak amacıyla uygulandı̆̆ını düşündüklerini dile getirmişlerdir. Çalışmamızla Aksoğan'ın (2020) araştırması bu açıdan benzerlik göstermektedir.

Araştırmaya katılan veliler; çocuklarının uzaktan eğitim sürecinde karşılaştıkları sorunları sıralamış, bu yöntemin temel dil becerilerini değerlendirmiş, motivasyon, sosyalleşme ve dikkatle ilgili 
fikir beyan etmiş, ödevlerin verimliliğini değerlendirmiş, yüz yüze eğitime dönme hususunda yorumda bulunmuşlardır. Velilerin bu aşamada verdikleri cevaplardan hareketle, çocuklarının uzaktan eğitim sürecini ilgiyle takip ettikleri, oluşan sorunları çözmeye çabaladıkları ve bu konuda duyarlı davranmaya gayret ettikleri sonucuna varılmaktadır. Başaran ve diğ. (2020)'nin araştırmasına katılan öğrenci velilerinin de uzaktan eğitimde çocuklarını destekleyici tutum takındıkları bulgulanmıştır. Bu bakımdan bu iki araştırma sonucunun benzeştiği söylenebilir.

Bütün bu sonuçlar bir arada değerlendirildiğinde uzaktan eğitim sürecine veli ve öğrencilerin tam anlamıyla intibak edemedikleri ve uzaktan eğitimle verilen eğitimin verimsiz olduğunu düşündükleri ortaya çıkmaktadır. Buna istinaden velilerin çoğunluğu, alışageldikleri geleneksel yüz yüze eğitim ortamına dönülmesi yönündeki taleplerini dile getirmişlerdir.

Araştırma kapsamında ulaşılan sonuçlar ışığında araştırmacılar tarafından aşağıdaki öneriler geliştirilmiştir:

- Bu çalışma, Manisa ilinin Salihli ilçesindeki 102 veliyle gerçekleştirilmiştir. Farklı ilçe ve şehirlerde yaşayan öğrenci velileriyle daha geniş kapsamlı çalışmalar yapılabilir.

- Bu çalışmada öğrenci velilerinin görüş ve düşünceleri Türkçe dersleri özelinde alınmıştır. Diğer derslere ilişkin veli görüş ve düşüncelerini ortaya çıkarmaya yönelik çalışmalar yapılabilir.

- Bu araştırmada, uzaktan eğitimin ortaokul öğrencilerinin temel dil becerilerine katkısı, velilerin bakış açısıyla ele alınmıştır. Bu eğitim yönteminin öğrencilerin dil becerilerine etkisinin nesnel bir biçimde araştırılması ve yüz yüze eğitimin çıktılarıyla karşılaştırılması alana katkı sunabilir.

- Uzaktan eğitime katılan öğrencilerin motivasyon düzeylerini artırmak için neler yapılması gerektiği hakkında daha derinlemesine araştırmalar yapılabilir.

- Uzaktan eğitime katılan öğrencilerin sosyalleşme düzeylerini artırmak uzaktan eğitim sistemi içerisinde akran etkileşimi için uygun ortamlar yaratılabilir.

- Uzaktan eğitimde yaşanabilecek teknik sorunlara karşın altyapı güçlendirme ve cihaz temin etme noktasında önlemler alınabilir.

- Velilerin uzaktan eğitim sürecinde paydaş olmaları ve süreci kolaylaştırmaları için onlara uzaktan eğitime ilişkin eğitimler verilmeli, karşılaşılan sorunları nasıl aşacakları ile ilgili bilgi verilebilir. Ayrıca MEB, okul yönetimleri, öğretmen, veli ve öğrencilerin uzaktan eğitime dair bilgi paylaşımında bulunabilecekleri platformlar oluşturulabilir.

- Uzaktan eğitim yöntemiyle Türkçe dersinin işlenişinin verimliliğini artırmak için gerekli çalışmalar yürütülebilir.

- Türkçe öğretmenlerinin uzaktan eğitim ortamlarında ders işlerken temel dil becerilerine dengeli bir şekilde alan açmaları sağlanabilir.

- Uzaktan eğitimde ödevlerin daha faydalı olması ve takibinin pratik bir şekilde yapılabilmesi için öğretmenlere hizmet içi eğitimler verilebilir.

\section{Araştırma ve Yayın Etiği}

Bu çalışmada "Yükseköğretim Kurumları Bilimsel Araştırma ve Yayın Etiği Yönergesi" kapsamında uyulması belirtilen tüm kurallara uyulmuştur. Yönergenin ikinci bölümü olan "Bilimsel Araştırma ve Yayın Etiğine Aykırı Eylemler" başlığı altında belirtilen eylemlerden hiçbiri gerçekleştirilmemiştir.

\section{Etik Kurul İni}

Kurul adı $=$ Yıldız Teknik Üniversitesi

Karar tarihi $=25.09 .2020$

Belge sayı numarası $=2009250012$

\section{Uygulama İzni}

Kurul adı = Milli Eğitim Bakanlığı

Karar tarihi $=27.11 .2020$

Belge sayı numarası $=17365429$ 


\section{Yazarların Katkı Oranı}

1.yazar $\% 25,2$. yazar $\% 25,3$. Yazar $\% 25,4$. Yazar $\% 25$ oranlarında olmak üzere tüm yazarlar bu çalışmaya eşit katkı sağlamışlardır.

\section{Çıkar Çatışması}

Bu araştırmada çıkar çatışması teşkil edebilecek herhangi bir durum söz konusu değildir.

\section{Kaynaklar}

Aksoğan, M. (2020). Opinions of students about distance education in the pandemi process. Naturengs, Special Issue, 1-9.

Akyol, H. (2016). Türkçe öğretim yöntemleri. Ankara: Pegem Yayınları.

Akyürek, M . (2020). Uzaktan eğitim: Bir alanyazın taraması. Medeniyet Eğitim Araştırmaları Dergisi, 4(1), 1-9.

Altıparmak, M., Kurt, I. D. ve Kapıdere, M. (2011, Şubat). E-öğrenme ve uzaktan eğitimde açık kaynak kodlu öğrenme yönetim sistemleri. XI. Akademik Bilişim Konferansı'nda sunulan bildiri, İnönü Üniversitesi, Malatya. Erişim adresi: https://ab.org.tr/ab11/kitap/altiparmak_kurt_AB11.pdf

Arat, T. ve Bakan, Ö. (2014). Uzaktan eğitim ve uygulamaları. Selçuk Üniversitesi Sosyal Bilimler Meslek Yüksekokulu Dergisi, 14(1-2), 363-374.

Ateş, V. (2010). Gazi Üniversitesi uzaktan eğitim programlarında kullanılmakta olan öğrenme yönetim sisteminin ders verenler açısından değerlendirilmesi. (Yayımlanmamış Yüksek Lisans Tezi). Gazi Üniversitesi Bilişim Enstitüsü, Ankara.

Bakioğlu, B. ve Çevik, M. (2020). Covid-19 pandemisi sürecinde fen bilimleri öğretmenlerinin uzaktan eğitime ilişkin görüşleri. Electronic Turkish Studies, 15(4), 109-129.

Başaran, M., Doğan, E., Karaoğlu, E. ve Şahin, E. (2020). Koronavirüs (covid-19) pandemi sürecinin getirisi olan uzaktan eğitimin etkililiği üzerine bir çalışma. Academia Eğitim Araştırmaları Dergisi, 5(2), 179-209.

Bayburtlu, Y. S. (2020). Covid-19 pandemi dönemi uzaktan eğitim sürecinde öğretmen görüşlerine göre Türkçe eğitimi. Electronic Turkish Studies, 15(4), 373-385

Bozkurt, A. ve Sharma, R. C. (2020). Emergency remote teaching in a time of global crisis due to Coronavirus pandemic. Asian Journal of Distance Education, 15(1), i-vi.

Can, E . (2020). Coronavirüs (Covid-19) pandemisi ve pedagojik yansımaları: Türkiye'de açık ve uzaktan eğitim uygulamaları. Açıöğretim Uygulamaları ve Araştırmaları Dergisi, 6(2) , 11-53.

Clark, J. T. (2020). Distance education. E. Iadanza (Ed.). Clinical Engineering Handbook (ss. 410-415). Floransa-italya: Academic Press.

Creswell, J. W. (2016). Nitel araştırma yöntemleri: beş yaklaşıma göre nitel araştırma ve araştırma deseni. Ankara: Siyasal Kitabevi.

Demir, E. (2014). Uzaktan eğitime genel bir bakış. Dumlupinar University Journal of Social Science, 39, 203-212.

Dinçer, S. (2006, Şubat). An overview of computer assisted education and distance learning. IV. Information Technologies Congress / Academic Informatics'te sunulan bildiri, Pamukkale Üniversitesi, Denizli.

Dinçer, S. (2018). Content analysis in scientific research: meta-analysis, meta-synthesis and descriptive content analysis. Bartın University Journal of Faculty of Education, 7(1), 176-190.

Doğan, Y. (2010). Dinleme becerisini geliştirmede etkinliklerden yararlanma. Türklük Bilimi Araştırmaları, 27, 263-274.

Duran, L. (2020). Distance learners' experiences of silence online: a phenomenological inquiry. International Review of Research in Open and Distributed Learning, 21(1), 81-98.

Elcil, Ş. ve Şahiner, D. (2014). Uzaktan eğitimde iletişimsel engeller. Sosyal ve Beşeri Bilimler Dergisi, 6(1), 21-33. 
Eren, E. (2020). Yeni Tip Koronavirüs' ün Türk eğitim politikaları uygulamalarına etkisi: Milli Eğitim Bakanlığının ve Yükseköğretim Kurulunun yeni düzenlemeleri. Yükseköğretim Dergisi, 10(2), 153-162.

Ferdousi, N. (2010). Distance education for law promotes gender equity in Bangladesh. Asian Journal of Distance Education, 8(1), 81-86.

Göçer, A. (2010). Türkçe öğretiminde yazma eğitimi. Uluslararası Sosyal Araştırmalar Dergisi, 3(12), 178-195.

Gümüşgül, O. ve Aydoğan, R. (2020). Yeni tip Koronavirüs-COVID-19 kaynaklı evde geçirilen boş zamanların ev içi rekreatif oyunlar ile değerlendirilmesi. Spor Eğitim Dergisi, 4(1), 107-114.

İnci Kuzu, Ç . (2020). Covid-19 pandemisi sürecinde uygulanan ilkokul uzaktan eğitim programı (Eba Tv) ile ilgili veli görüşleri. Millî Eğitim Dergisi, Salgın Sürecinde Türkiye'de ve Dünyada Eğitim, 49(1), 505-527.

Kan Kılınç, B., Yazıcı, B., Günsoy, B. ve Günsoy, G. (2020). Perceptions and opinions of graduates about the effects of open and distance learning in Turkey. Turkish Online Journal of Distance Education, 21(1), 121-132.

Kantos, Z. E. (2020, Ağustos). Sınıf öğretmenlerinin uzaktan eğitim ile ilgili düşünceleri. 8. Uluslararası Bilimsel Araştırmalar Kongresi'nde sunulan bildiri, Hattuşa, Çorum.

Karakuş, N., Ucuzsatar, N., Karacaoğlu, M. Ö., Esendemir, N. ve Bayraktar, D. (2020). Türkçe öğretmeni adaylarının uzaktan eğitime yönelik görüşleri. RumeliDE Dil ve Edebiyat Araştırmaları Dergisi, $19,220-241$.

Keskin, M. ve Kaya, D. Ö. (2020). Covid-19 sürecinde öğrencilerin web tabanlı uzaktan eğitime yönelik geri bildirimlerinin değerlendirilmesi. İzmir Katip Çelebi Üniversitesi Sağlık Bilimleri Fakültesi Dergisi, 5(2), 59-67.

Khan, H. ve Williams, J. B. (2007). Poverty alleviation through access toeEducation: can e-Learning deliver? (U21Global Working Paper, No. 002/2006) in "Poverty, Poverty Alleviation, and Social Disadvantage: Analysis, Case Studies and Policies", Eds. C. A. Tisdell. New Delhi: Serials Publications.

Kırık, A . (2016). Uzaktan eğitimin tarihsel gelişimi ve Türkiye'deki durumu. Marmara Illetişsim Dergisi, 21, 73-94.

MEB. (2020). Bakan Selçuk, koronavirüs'e karşı eğitim alanında alınan tedbirleri açıkladı. Erişim adresi: http://www.meb.gov.tr/bakan-selcuk-koronaviruse-karsi-egitim-alaninda-alinan-tedbirleriacikladi/haber/20497/tr

Merriam, S. B. (2018). Nitel araştırma desen ve uygulama için bir rehber. Ankara: Nobel Akademi.

Miles, M. B. ve Huberman, A. M. (2016). Nitel veri analizi. Ankara: Pegem Akademi.

Odabaş, H. (2003). İnternet tabanlı uzaktan eğitim ve bilgi ve belge yönetimi. Türk Kütüphaneciliği, $17(1), 22-36$.

OECD. (2001). Understanding the digital divide. Paris: OECD Publications. Erişim adresi: https://www.oecd.org/sti/1888451.pdf

Özdemir, M . (2010). Nitel veri analizi: sosyal bilimlerde yöntembilim sorunsalı üzerine bir çalışma. Eskişehir Osmangazi Üniversitesi Sosyal Bilimler Dergisi, 11(1), 323-343.

Öztürk, L. (2002). Dijital uçurumun küresel boyutları. Ege Akademik Bakış Dergisi, 2(1), 1-10.

Öztürk, L. (2005). Türkiye'de dijital eşitsizlik: Tübitak-bilten anketleri üzerine bir değerlendirme. Erciyes Üniversitesi iktisadi ve Idari Bilimler Fakültesi Dergisi, 24, 111-131.

Saban, A. ve Ersoy, A. (2017). Eğitimde nitel araştırma desenleri. Ankara: Anı Yayıncılık.

Sezgin, S. ve Fırat, M . (2020). Covid-19 pandemisinde uzaktan eğitime geçiş ve dijital uçurum tehlikesi. Açıöğretim Uygulamaları ve Araştırmaları Dergisi, 6(4), 37-54.

Sirem, Ö. ve Baş, Ö. (2020). Okuma güçlüğü olan ilkokul öğrencilerinin covid-19 sürecinde uzaktan eğitim deneyimleri. Electronic Turkish Studies, 15(4), 993-1009.

Telli Yamamoto, G. ve Altun, D. (2020). Coronavirüs ve çevrimiçi (online) eğitimin önlenemeyen yükselişi. Üniversite Araştırmaları Dergisi, 3(1), 25-34.

Traxler, J. (2018). Distance learning - predictions and possibilities. Education Sciences, 8(35), 1-13. 
UNESCO. (2020). COVID-19 educational disruption and response. Erişim adresi: https://en.unesco.org/covid19/educationresponse

Ustati, R. ve Hassan, S. S. S. (2013). Distance learning students' need: evaluating interactions from Moore's theory of transactional distance. Turkish Online Journal of Distance Education, 14(2), 292-304.

Uşun, S. (2006). Uzaktan eğitim. Ankara: Nobel Yayın Dağıtım.

Wheeler, S. (2002). Student perceptions of learning support in distance education. Quarterly Review of Distance Education, 3(4), 19-29

WHO. (2020). Coronavirus disease (COVID-19) Pandemic. Erişim adresi: https://www.who.int/emergencies/diseases/novel-coronavirus-2019

Yamamoto, G. T. ve Can, E. (2013). Türkiye'de uzaktan eğitim uygulamalarının analizi. Yüzer, V., Yamamoto, G. T. ve Demiray U. (Ed.), Türkiye'de E-öğrenme: Gelişmeler ve uygulamalar IV (ss. 193-206). Eskişehir: Anadolu Üniversitesi Açıköğretim Fakültesi Yayınları.

Yaşar, ş. (2010). Yapılandırmacı yaklaşımda öğretmenin, öğrencinin ve velinin rolü. Eğitime Bakış Dergisi, 17, 15-19.

Yıldırım, A. ve Şimşek, H. (2016). Sosyal bilimlerde nitel araştırma yöntemleri. Ankara: Seçkin Yayıncılık. Yılmaz, E., Mutlu, H. ve Doğanay, G. (2020). Veli algısına göre pandemi dönemi uzaktan eğitim sürecinin niteliği. Konya: Palet Yayınları.

\section{Extended Abstract}

\section{Introduction}

The Covid-19 virus, which broke out in Wuhan, People's Republic of China in late 2019 and spread all over the world in 2020, has deadly effects. Various measures have been taken in all areas in order to reduce life-threatening risks and prevent the spread of the virus. Education is also among the instutions of great change and transformation due to Covid-19.

One of the most important changes seen in the field of education is the transition of schools from face-to-face education to distance education. Such a significant change had different effects on teachers, students and parents. When the literature on distance education is examined, it has seen that almost all stakeholders of the education have been researched, on the other hand, students' parents are subject to fewer studies. No independent study was found in which parents' opinions were sought regarding the implementation of Turkish education in the distance education process. For his reason, the aim of this study is to examine middle school parents' opinions about Turkish lessons taught in the distance education process.

For this purpose online interviews with parents of middle school students residing in Turkey's Aegean region, Salihli province of Manisa, in the country was carried out. A total of 102 parents of students residing in Manisa province were reached within the scope of the research. The parents were asked questions about technical problems encountered in distance education, motivation, socialization, attention, basic language skills, homework status and follow-up, and educational efficiency.

\section{Method}

This research was carried out with case study design, which is one of the qualitative research methods. In the study, parents' views on distance education were handled as a single unit of analysis, and the study was structured with a holistic single-case pattern in which a situation is analyzed in a holistic manner. The study group of the research consists of 102 parents of middle school students residing in Salihli district of Manisa province.

The data collection tool of the research is a 21-item questionnaire, prepared online via Google Forms, structured in line with the opinions of field experts. The first 7 items of the questionnaire consist of questions about the demographic information of the parents of the students. In this part, age, profession, gender, educational status, tools used in distance education, distance education usage and class level information of students were asked. In the remaining 14 items, there are grading scales 
for determining the opinions of parents of students on the distance education process in terms of Turkish education and open-ended questions about their causality.

Both content analysis and descriptive analysis were used for the analysis of the data. The data categorized by content analysis were interpreted with descriptive analysis.

\section{Result and Discussion}

In this study, the opinions of the parents of middle school students regarding the distance education process that started with the Covid-19 outbreak were taken specifically for Turkish lessons. In the study, it was found that there are technical problems in distance education. It has been concluded that the participants generally did not know or used distance education in the pre-epidemic period. Those who have previous distance education experience overcome technical problems more easily.

In line with the opinions of the participants, it was determined that the distance education method affects students' attention at a high level. This situation can be read as a result of the fact that technological equipment draws the attention of students in Generation $Z$ and this situation is observed by the parents.

According to the participants, distance education contributes moderately to student motivation. This result can be related to the students' being born in a digital age and their familiarity with technological tools. Devices such as televisions, tablets, phones and computers used as channels in distance education may have attracted the attention of children.

Student parents stated that distance education negatively affected students' socialization. It is an expected situation that children who are connected to distance education via technological equipment without any physical classroom environment cannot have a traditionally perceived socialization opportunity.

In terms of the effect of distance education on language skills, it was found that listening skill was developed at a high level, speaking and reading skills were moderately supported, and writing skills were developed at a low level. Parents of the students, who are the participants of the study, may have expressed their opinions in this direction, considering the listening and speaking actions that are most commonly used in distance education.

According to the parents of the students, it is difficult to follow homework in distance education.

When all these results are evaluated together, it is revealed that parents and students cannot fully adapt to the distance education process and they think distance education is inefficient. Based on this, the majority of the parents expressed their demands for a return to the traditional face-to-face education environment they are used to. 